Staff Working Paper/Document de travail du personnel 2017-14

\title{
Strategic Complementarities and Money Market Fund Liquidity Management
}

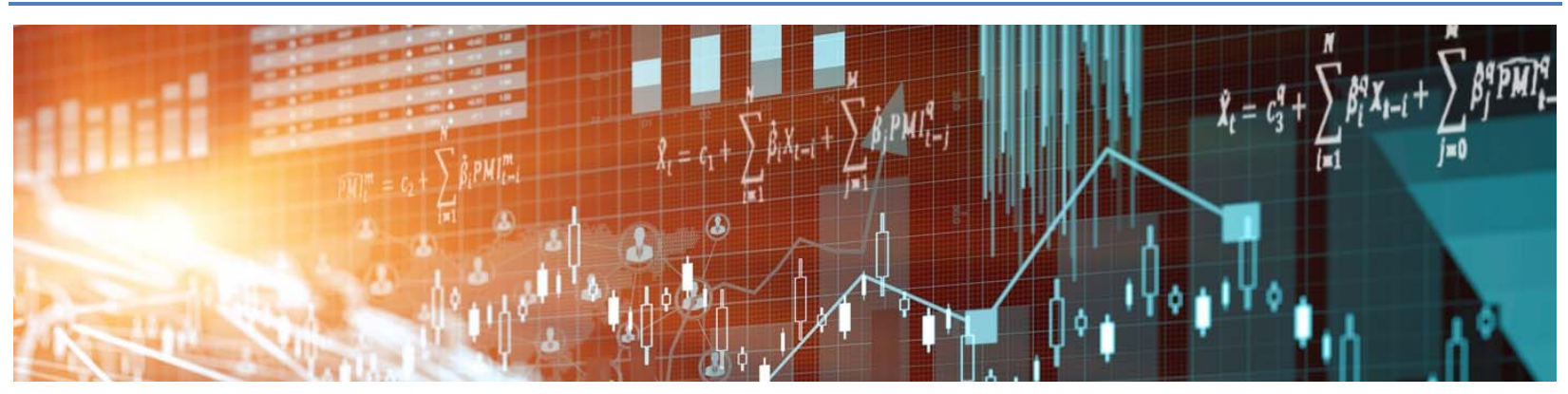

by Jonathan Witmer 
Bank of Canada Staff Working Paper 2017-14

April 2017

\title{
Strategic Complementarities and Money Market Fund Liquidity Management
}

\author{
by \\ Jonathan Witmer \\ Financial Markets Department \\ Bank of Canada \\ Ottawa, Ontario, Canada K1A 0G9 \\ jwitmer@bankofcanada.ca
}




\section{Acknowledgements}

I thank Greg Bauer, Sermin Gungor, Jesus Sierra Jimenez, David Rakowski, Chris Sutherland, Jing Yang and seminar participants at the Bank of Canada and the Financial Management Association meetings for their helpful comments. All remaining errors are my own. 


\begin{abstract}
Following the financial crisis, there has been increased regulatory focus on the management of liquidity in mutual funds and, specifically, whether funds hold enough liquidity to guard against the potential for investor runs. Using a novel, detailed regulatory dataset on the portfolio holdings of US money market funds, I find that internal prime money market fundsthose that manage the liquidity of other funds in the fund family-have lower liquidity than external prime funds. This suggests that money market funds hold more liquidity to reduce the potential for strategic complementarities (i.e., incentives to run) in investor redemptions, because the family funds that invest in these internal funds should be able to coordinate their redemption decisions. Additionally, at quarter ends, when non-US bank dealers reduce their repo funding (Munyan, 2015), I find that prime money market funds reduce their overnight liquidity, which consists primarily of overnight repos. External prime money market funds do not let this decreased cash demand from non-US bank dealers reduce their liquidity as much as internal funds do. This all suggests that these external prime money market funds are more concerned about overnight liquidity, consistent with greater concern about potential investor strategic complementarities.
\end{abstract}

Bank topics: Financial markets; Financial institutions

JEL codes: F30; G01; G18; G20

\title{
Résumé
}

Après la crise financière, les autorités de réglementation ont porté leur attention sur la manière dont les fonds communs de placement gèrent la liquidité, en se demandant tout particulièrement si ces entités disposent d'assez de liquidités pour faire face à une éventuelle panique des investisseurs. À partir d'un nouvel ensemble de données réglementaires détaillées sur les actifs de portefeuille des fonds du marché monétaire américain, nous constatons que les fonds internes de premier ordre - ceux qui gèrent la liquidité d'autres fonds de la famille de fonds - conservent moins de liquidités que les fonds externes de premier ordre. Ce constat laisse penser que les fonds du marché monétaire conservent plus de liquidités afin de réduire les possibilités de complémentarités stratégiques (c.-à-d. les possibilités de retraits massifs) dans les demandes de remboursement des investisseurs, car les fonds d'une même famille qui investissent dans ces fonds internes devraient pouvoir coordonner leurs décisions de remboursement. En outre, nous constatons qu'en fin de trimestre, au moment où les opérateurs bancaires non américains réduisent les montants affectés aux financements par opérations de pension (Munyan, 2015), les fonds de premier ordre réduisent leurs liquidités à un jour, qui sont essentiellement constituées de titres faisant l'objet d'opérations de pension à un jour. Les fonds externes de premier ordre ne laissent pas cette diminution de la demande de liquidités de la part des opérateurs bancaires non américains faire baisser leurs liquidités autant que les fonds internes. Tout cela paraît montrer que ces fonds externes de premier ordre se préoccupent davantage de la liquidité à un jour, une attitude qui reflète leur inquiétude grandissante à l'égard des complémentarités stratégiques entre investisseurs.

Sujets : Marchés financiers ; Institutions financières

Codes JEL : F30 ; G01 ; G18 ; G20 


\section{Non-Technical Summary}

Mutual funds, and money market funds in particular, may have two motives for holding liquidity. First, a money market fund may hold liquid assets to reduce transactions costs. When an investor redeems from the fund, the money market fund can meet the redemption request out of its liquid assets. If the money market fund does not hold enough liquid assets to meet its redemption requests, it would need to sell illiquid assets and incur additional transaction costs in doing so. By increasing its liquid asset holdings, the fund can lower the potential transaction costs associated with investor redemptions. However, there is an opportunity cost of holding liquid assets, in that liquid assets have lower yields. Therefore, theory would predict that funds have an optimal level of liquid assets that balances the reduced yield against the transaction cost savings of holding liquid assets.

Second, money market funds may hold additional liquidity to lower the likelihood of an investor run. Following the financial crisis, there has been increased regulatory focus on mutual fund liquidity management and, specifically, whether funds hold enough liquidity to guard against the potential for investor runs. When a fund incurs transactions costs to meet investor redemptions, there is a first mover advantage: the investor redeeming from the fund is paid a share price that may not fully account for the transaction costs the fund will incur later in selling assets to meet the redemption request. Investors remaining in the fund will absorb the additional transaction costs caused by the early redeemer's redemptions. Therefore, shareholders may redeem their shares in a fund early on the self-fulfilling belief that other shareholders are doing the same, especially in those funds that have higher transaction costs associated with fund redemptions. To mitigate this effect, funds could hold a higher level of liquid assets to reduce the transaction costs redeeming shareholders place on remaining shareholders.

To differentiate between these two separate motivations for holding liquidity, I use the fact that some money market funds are used primarily as a liquidity management tool by other funds within the same mutual fund family. Presumably, these family funds are aware of each other's decisions to redeem from the family money market fund and can coordinate their redemption decisions so as to avoid unwanted runs. If this is the case, these "internal" funds should hold less liquidity than comparable "external" funds.

Using a novel, detailed regulatory data set on the portfolio holdings of US money market funds, I find that internal prime money market funds do have lower liquidity than external prime funds. Additionally, at quarter-ends, when non-US bank dealers reduce their repo funding (Munyan, 2015), I find that prime money market funds reduce their overnight liquidity, which consists primarily of overnight repos. External prime money market funds do not let this decreased cash demand from non-US bank dealers reduce their liquidity as much as internal funds do. This all suggests that these external prime money market funds are more concerned about overnight liquidity, consistent with greater concern about potential investor strategic complementarities. 


\section{Introduction}

Do money market funds hold more liquidity to guard against investor runs? How mutual funds manage their liquidity is one of the most heavily debated topics among mutual fund regulators and industry participants, but there is only a small body of academic literature on the topic. Theoretically, if liquidity reduces the negative externality that redeeming shareholders impose on remaining shareholders, it may reduce the likelihood that investors redeem their shares based on the self-fulfilling belief that other investors are also redeeming their shares (Chen, Goldstein and Jiang, 2010). Indeed, the regulatory focus on money market fund liquidity is often justified on the basis that liquidity can help prevent investor runs. For example, in 2010, the US Securities and Exchange Commission (SEC) mandated that money market funds maintain a minimum level of liquidity. Industry participants were generally receptive to these SEC changes, but were opposed to other proposed changes at the time, such as mandating a floating share price or implementing gates to manage a fund's liquidity (Investment Company Institute, 2012a, 2012b).

The literature suggests that mutual funds have two motives for holding liquid assets. The first is a transaction cost motive: by holding liquid assets, a fund can have reduced transaction costs by selling liquid assets rather than illiquid assets to satisfy investor redemptions. Since liquid assets have a lower yield than illiquid assets, funds have an optimal amount of liquidity that trades off reduced transaction costs against lower returns. This trade-off has been modeled in the context of a firm's cash management problem (Miller and Orr, 1966) and in the context of a mutual fund's optimal liquidity level (e.g., Chernenko and Sunderam, 2015). ${ }^{1}$ Second, mutual funds may hold additional liquidity to address strategic complementarities in their investors' redemption decisions. In the presence of strategic complementarities, shareholders may redeem their shares in a fund based on the self-fulfilling belief that other shareholders are doing the same, especially with funds that have higher transaction costs associated with fund redemptions (Chen, Goldstein and Jiang, 2010). The mechanism is similar to the mechanism in a bank run. Other investors may be redeeming from the fund at the fixed $\$ 1$ share price, and the mutual fund may have to pay transaction costs to liquidate some of its holdings. These liquidity costs are borne by those shareholders remaining in the fund, since the fund liquidates its holdings after the early investors redeem. Thus, the more investors that are redeeming, the more incentive there may be to redeem as well to avoid being a remaining shareholder that absorbs these redemption costs. To mitigate this effect, funds should hold a higher level of

\footnotetext{
${ }^{1}$ The classic Miller and Orr (1966) model of cash management by firms relates closely to the management of liquidity in mutual funds. The decision maker in the Miller-Orr model is holding two assets: cash and a portfolio of assets such as commercial paper and certificates of deposit. The assets provide a higher yield than the cash balances, but the fund must also incur a constant transaction cost (independent of the size of the transaction) in switching between the liquid assets and cash balances.
} 
cash or liquid assets to reduce the negative externality that redeeming shareholders place on remaining shareholders (Liu and Mello, 2011).

It is a challenge to distinguish between these two motives empirically. For example, the transaction cost motive would predict that certain funds should hold higher cash balances. In particular, funds with higher transaction costs (associated with illiquid assets), funds with more volatile investor flows and funds with a low opportunity cost of holding cash (i.e., the yield differential between cash and less liquid assets) should hold higher cash balances (Miller and Orr, 1966, Chernenko and Sunderam, 2015). However, global games models with strategic complementarities predict a similar effect on cash holdings. Liu and Mello (2011) show that funds will hold more cash when fund investors cannot coordinate their redemption decisions and hence may redeem on the belief that other investors are also redeeming. Regardless of whether investors can coordinate, this model also shows that funds will hold more cash when there is a low opportunity cost of holding cash, when transaction costs are high, and when ex-ante expected investor outflows are higher.

The literature has found empirical support for both hypotheses in equity funds. Funds that have more illiquid assets have higher cash holdings (Chernenko and Sunderam, 2015; Massa and Phalippou, 2005), and equity funds increase cash after their portfolio liquidity decreases (Rzeznik, 2015). Equity funds that transact more frequently also have higher portfolio liquidity (Massa and Phalippou, 2005). Moreover, funds with institutional investors and a higher volatility of investor flows hold higher cash balances (Chernenko and Sunderam, 2015; Chordia, 1996). Chordia (1996) also shows that funds use front- and back-end load fees to discourage redemptions, and funds with these fees hold more illiquid assets. Similarly, consistent with Vayanos' (2004) model, funds increase cash balances when market volatility increases, as this volatility may be associated with investor future redemptions (Huang, 2015; Rzeznik, 2015). Funds also reduce portfolio illiquidity by selling more illiquid stocks during periods of market uncertainty (Ben-Raphael, 2014).

However, to date and to the best of my knowledge, no other paper has examined liquidity in money market funds. I focus on money market funds for five reasons. First, money market funds are large participants in the market, accounting for $18 \%$ of the $\$ 15.7$ trillion in US mutual fund assets as of December 2015 (Investment Company Institute, 2016). Second, liquidity management is more important in money market funds than in other mutual funds since they themselves are a source of liquidity for their clients. Thus, their inflows and outflows are more likely the result of investor liquidity shocks and less likely related to the expected future performance of the fund. Third, the management of liquidity is presumably more important in money market funds given their usage of a fixed share price. This makes the probability of 
large investor redemptions more likely (e.g., Witmer, 2016) and hence the management of liquidity more important. Indeed, the 2010 SEC liquidity regulations were targeted towards money market funds and not at mutual funds more generally. Fourth, I utilize a novel dataset of detailed securities-level holdings of all US money market funds. The money market fund data are standardized and available at a monthly frequency and, as such, are more conducive to analyzing fund liquidity management (Elton et al., 2010). For example, these data can be used to i) calculate and evaluate different measures of liquidity, ii) construct variables based upon the liquidity and risk characteristics of the fund's detailed holdings and iii) estimate a fund's adjustment to liquidity shocks at a higher frequency (i.e., monthly rather than quarterly). ${ }^{2}$ Fifth, the money market fund data can be used to distinguish between the transaction cost and strategic complementarities motivations for holding cash.

In this paper, to distinguish between these two motivations, I use the fact that some funds do not have the same degree of strategic complementarities among their investors. Specifically, some money market funds are used to manage the cash and liquidity holdings of other mutual funds within the fund family. For example, the Vanguard Market Liquidity fund is a "...cash management vehicle for the Vanguard funds and certain trusts and accounts managed by Vanguard or its affiliates. The Fund is not available to other investors." ${ }^{3}$ It seems reasonable to assume that funds within the family would share information on their redemptions and purchases of their own family money market fund. This would reduce the strategic complementarities and cash holdings through two channels. ${ }^{4}$ First, the funds can make redemption decisions as if they were one large investor. In the Chen, Goldstein and Jiang (2010) model, the strategic complementarity in the redemption decision is reduced as the relative size of the largest investor increases. In essence, the investor begins to internalize the negative externality as he becomes a larger shareholder. In the limit, when the investor owns all of the shares of the fund, this negative externality disappears since he would bear the full costs of his redemption decision. Second, funds within the family may be concerned about negative spillovers of problems in its money market fund to other funds within the family (Kasperczyk and Schnabl, 2013) and may coordinate redemption decisions to minimize these spillovers. Bhattacharya, Lee and Pool (2013), for example, show that funds of funds provide liquidity to the family funds they invest in when other investors are withdrawing.

\footnotetext{
${ }^{2}$ There is evidence that funds have window-dressed around calendar year-end (Musto, 1997, 1999). However, given increased scrutiny by investors and regulators and the requirement to report at a monthly frequency, this is less likely to affect the results during our sample period.

3 http://www.vanguard.com/pub/Pdf/i1142.pdf

${ }^{4}$ Family funds could also coordinate their redemption decisions to reduce the volatility of flows in their internal money market fund, which would reduce transaction costs and imply a transaction cost motive for lower liquidity. My analysis includes measures of flow volatility to account for any possibility that differences in flow volatility could be responsible for a lower overnight liquidity level in internal funds.
} 
In the cross-section of money market fund data, I find evidence suggesting that funds do hold more liquidity when they are concerned about strategic complementarities. Even after accounting for other variables that affect fund liquidity, money market funds that are held more by other mutual funds in the same family hold less overnight liquidity (i.e., assets that mature the next business day). Since money market mutual funds often offer same-day settlement of transactions (including payment of cash), they may wish to have securities maturing the next business day, such as repos, that can also be settled should the fund receive redemptions that day. Supporting this, the results suggest that money market funds more carefully manage their overnight liquidity by returning it towards target levels faster than other measures of liquidity. Consistent with concerns over strategic complementarities, like others, I also find that funds with institutional investors and funds with more volatile investor flows tend to hold more liquidity.

Strategic complementarities also affect how funds dynamically adjust their liquidity. I use an exogenous reduction in cash demand at quarter end from non-US bank dealers to identify differences in how external and internal money market funds react to a reduction in repo activity, which is the main component of overnight liquidity. Munyan (2015) and Anbil and Senyuz (2016) find evidence of a reduction in the repo books of non-US bank dealers around quarter end. They attribute this to windowdressing incentives, since some European bank dealers can calculate regulatory ratios based on quarter-end snapshots. They provide evidence that this drop is due to reduced cash demand from bank dealers, rather than from reduced supply by other participants such as money market funds. At quarter end, internal funds reduce their overnight liquidity more than external funds do, even after controlling for fixed fund effects. This suggests that external money market funds are more concerned about their overnight liquidity levels. Given that external funds have more strategic complementarities than internal funds, the implication is that these money market funds may be holding more liquidity to reduce the potential for investor runs.

With proportional transaction costs, funds should find it optimal to maintain liquidity within a range of values rather than at a single optimal value (Constantinides, 1986; Miller and Orr, 1966). ${ }^{5}$ In essence, funds should maintain liquidity within an optimal zone and only adjust liquid asset balances once liquidity approaches the boundaries of this zone. Theory predicts that this zone is larger when the illiquid assets' transaction costs are higher, when fund flow volatility is higher, and when the opportunity cost of holding liquidity is low (Miller and Orr, 1966). In addition, if a fund uses liquidity to reduce the potential for investor runs, it should maintain a higher minimum level of liquidity so that its liquidity does not become so low that it could potentially lead to more investor redemptions. Indeed, I find that prime funds that have more

\footnotetext{
${ }^{5}$ Fischer, Heinkel and Zechner (1989) develop an analogous model on the liability side of a firm's balance sheet (i.e., optimal capital structure) in the presence of proportional transaction costs, and find a similar result in that the capital structure is adjusted once it reaches an upper or lower bound.
} 
strategic complementarities among investors - those that are not held by other mutual funds in the same family—have a higher minimum liquidity level.

Investor flows and changes in a fund's investment portfolio could lead to deviations in a fund's liquidity from its target level. Funds face adjustment costs in bringing their liquidity towards their target level. I use a partial adjustment model to estimate how quickly funds reduce deviations of their current liquidity level from their target liquidity level. On the one hand, funds more concerned about investor strategic complementarities should quickly return liquidity towards target levels, since this could reduce the incentives to run in future periods. On the other hand, the fund may want to rebuild its liquidity buffer more slowly to reduce fire-sale-related transaction costs to reduce the incentives to run in the current period. Zeng (2016) suggests that, when shareholders are more likely to run, funds would employ a more rapid cash rebuilding policy. Overall, the evidence for this story is mixed, given that external prime funds adjust one measure of liquidity more quickly toward target, and adjust a different measure of liquidity more slowly toward target. Specifically, I find that external prime funds adjust "daily liquid assets" (a liquidity measure defined by the Securities and Exchange Commission that must be greater than $10 \%$ of a money market fund's portfolio assets) more quickly back toward target liquidity. In contrast, relative to internal funds, external funds adjust their overnight liquidity (i.e., overnight reverse repos) more slowly toward target. It may be that, since their level of overnight liquidity is much higher than that of internal funds, external funds do not need to adjust overnight liquidity as quickly.

The rest of the paper is organized as follows. In the next section, I discuss the factors influencing fund liquidity levels and further develop the hypotheses discussed above. In Section 3, I describe the data and report summary statistics. The estimation results are discussed in Section 4. In Section 5, I discuss robustness checks and provide some concluding remarks in Section 6.

\section{Hypothesis Development}

Funds may hold cash (or other forms of liquidity) to minimize expected transaction costs of the fund as well as the opportunity cost of holding cash. For example, in the Miller-Orr (1966) model, the firm receives random cash flows (investor flows in the context of mutual funds), and the decision maker's objective is to minimize the cost of managing the firm's cash balances, which includes both the transaction costs as well as the lower yield of the liquid assets relative to the rest of the portfolio. With lumpy transaction costs, the firm follows a policy rule whereby it allows the cash balance to fluctuate within certain bounds, and once it reaches either of these bounds, a transaction is made such that the cash balance returns to a 
specific target level. When these transactional costs are proportional, the firm will transact to keep the cash balance from crossing these upper and lower thresholds, but will not return cash to a specific target level. Thus, the firm faces a trade-off: holding lower cash balances results in a lower opportunity cost of holding cash, but also results in a higher transaction cost since the firm's cash balance is more likely to fall to zero and the firm must sell less liquid assets (and pay accompanying transaction costs) once cash falls to that point. The model predicts that the firm's average optimal cash balance is increasing in the variance of cash flows, and is also increasing in transaction costs and decreasing in the opportunity cost of cash.

Prime money market funds hold securities that have more credit risk and are less liquid than Treasuries, such as commercial paper and asset-backed commercial paper. Covitz and Downing (2007) show that the secondary market for commercial paper is very thin, and that liquidity is a major determinant of commercial paper spreads. Thus, there may be negative externalities associated with investor redemptions. Given that prime money market funds are exposed to credit risk (and allow for daily redemptions), they are also exposed to the potential for investor runs. For example, the run on the Primary Reserve Fund in 2008 was a result of losses on holdings of Lehman Brothers securities.

Money market funds may also hold liquid assets to guard against the potential for shareholders to exit the fund en masse (i.e., strategic complementarities in redemption decisions). Mutual fund investors may make redemption decisions based on the anticipated redemption decisions of other investors in the mutual fund, because the transaction costs to meet these redemption requests (e.g., Edelen, 1999) are borne by investors remaining in the fund (Chen, Goldstein and Jiang, 2010). In money market funds, redeeming investors are paid a constant $(\$ 1)$ share price, and if the fundamental value of the fund drops below $\$ 1$, it places an even larger externality on remaining investors, much like externalities in typical models of bank runs (e.g., Diamond and Dybvig, 1983; Goldstein and Pauzner, 2005). ${ }^{6}$ Because of the possibility of fragility, money market funds may prefer to hold more cash than they would in the absence of this externality. This cash serves two purposes. First, it would reduce transaction costs associated with complementarity-driven redemptions and, second, it could be used as a signalling device to reduce the likelihood of these redemptions occurring (Liu and Mello, 2011).

I use a measure of strategic complementarities in money market funds to distinguish between the transaction-based explanation and the strategic complementarities explanation for holding cash. Negative externalities are less severe when there is a large investor in the fund (Chen, Goldstein and Jiang, 2010). Essentially, other investors' early redemption behaviour has a smaller negative effect on the large investor's

\footnotetext{
${ }^{6}$ Witmer (2015) finds that money market funds with a fixed share price experienced more redemptions during the crisis than those with a floating share price. McCabe (2010), Kasperczyk and Schnabl (2013), and Schmidt, Timmerman and Wermers (2016) also show that there were more redemptions during the crisis in those money market funds that held riskier assets.
} 
payoff since, in the aggregate, they represent a smaller fraction of the overall fund. The other investors, knowing that the large investor is less likely to redeem early, are also less likely to redeem early themselves. To elucidate, were the fund to be owned by a single investor, there would be no coordination problem and hence no negative externality. In this paper, the proportion of each money market fund that is held by other mutual funds in the same family is used as a measure of the size of the largest investor. Since these mutual funds are within the same fund family, they may coordinate their redemption decision to limit the potential for destabilizing dynamics, especially if they think that a run on their money market fund could transmit to other funds in the family (Kasperczyk and Schnabl, 2013). I call funds that are marketed predominantly to outside investors "external money market funds," and those that are used as a cash management tool for other funds in the family "internal money market funds." These internal money market funds have, on average, about $45 \%$ of their shareholder base from funds within the family and should thus have fewer strategic complementarities. To prevent externality-driven investor redemptions, an external money market fund may choose to hold more liquid asset balances (e.g., holdings that mature overnight) above and beyond what would be required to reduce transaction costs. This leads to the first hypothesis:

Hypothesis 1: External prime money market funds hold more liquid asset balances.

In addition, external money market funds may react differently to an exogenous reduction in overnight liquidity. At quarter end, evidence suggests that some non-US bank dealers window-dress their repo books, resulting in a reduction in cash demand and a reduction in money market funds' reverse repo positions in their portfolios (Munyan, 2015). This reduction in repo is sizeable, as Munyan (2015) estimates that these non-US bank dealers remove about $\$ 170$ billion from the tri-party repo market around quarter end. Anbil and Senyuz (2016) attribute this window-dressing behavior to regional differences in the implementation of Basel III regulations. In particular, US banks are required to report leverage ratios based on daily averages of on-balance-sheet items. In contrast, non-US dealers can calculate the ratio based on month-end or quarter-end snapshots. Hence, this latter group of dealers may have an incentive to reduce their repo books at quarter end to reduce their reported leverage ratios.

This reduction in non-US bank dealer repo activity should result in a reduction in money market fund usage of reverse repos, which is the main aspect of their overnight liquidity. And, when bank dealers reduce their repo funding, they have less need for Treasuries and Agencies as collateral behind their repo funding. Money market funds need to replace their reduced overnight reverse repo positions with something, and given the reduced collateral needs of non-US bank dealers, money market funds may end up increasing their positions in short-term Treasury and Agency securities. This lowers the overnight liquidity measure because Treasury positions are not considered as liquid as reverse repo positions: money 
market funds have to incur transaction costs to liquidate their securities positions, whereas overnight reverse repos naturally mature the next day. Strategic complementarities may affect how money market funds respond to this reduction in cash demand, which, as argued above, would lead to a decrease in the money market fund's overnight liquidity. Funds that are less concerned about their overnight liquidity levels should absorb a larger decrease in overnight liquidity resulting from quarter-end effects. Thus, although internal funds are expected to have a lower average level of cash balances than external funds, this difference should become even more pronounced at quarter ends.

However, the Federal Reserve introduced an Overnight Reverse Repo Facility in September 2013. Money market funds used this facility more at quarter end, which alleviated the impact of window-dressing by non-US bank dealers on their reverse repo holdings. This is because money market funds could replace the reduced reverse repo to these non-US bank dealers with reverse repo to the Federal Reserve. Thus, this difference between internal and external funds should be evident only before the introduction of the Overnight Reverse Repo Facility.

Hypothesis 2: Money market funds will reduce their overnight liquidity at quarter ends prior to the introduction of the Overnight Reverse Repo Facility. External prime money market funds will have a smaller reduction in overnight liquidity at quarter ends. There will be no effect of quarter ends on overnight liquidity after the introduction of the Overnight Reverse Repo Facility.

With proportional transaction costs, funds should find it optimal to maintain liquidity within a range of values rather than at a single optimal value (Constantinides, 1986; Miller and Orr, 1966). In essence, they should maintain liquidity within an optimal no-trade zone and only adjust liquid asset balances once liquidity approaches the boundaries of this zone. For funds that are trying to minimize transaction costs, theory predicts that this no-trade zone is larger when the illiquid assets' transaction costs are higher, when fund flow volatility is higher, and when the opportunity cost of holding liquidity is low (Miller and Orr, 1966). Put another way, money market funds may also adjust their liquidity more slowly back to target in the presence of transaction costs.

Over time, fund liquidity may also be affected by investor flows. In theory, since funds should maintain their liquidity within an optimal range in the presence of transaction costs to avoid constantly rebalancing their portfolio, fund liquidity will be affected by concurrent investor flows. For example, if fund liquidity is in the bottom of this optimal range, when the fund receives investor inflows it should allow its liquidity to increase, as long as these inflows do not make the fund exceed the top of its optimal liquidity range. In practice, funds that receive inflows allow their levels of liquidity to increase (Massa and Phalippou, 2005). In addition, Dubofsky (2010) finds that international funds allow flows to accumulate 
into cash more than domestic funds. Since international funds hold more illiquid assets than domestic funds, he argues that this finding is consistent with these funds minimizing transaction costs that could be caused by this flow.

However, funds may not want their liquidity to deviate too much from an optimal level if they are concerned about the potential for investor runs. Since the probability of an investor run is a function of the fund's cash holdings, funds with more potential for runs will not want their cash holdings to deviate too much below the optimal cash holdings level. This suggests that these funds will have a higher minimum in their cash holdings. There is a trade-off and potential time inconsistency problem in how funds dynamically optimize their portfolio liquidity (Zeng, 2016). On the one hand, a fund may be able to reduce the probability of a run in the current period if it rebuilds its fund liquidity more slowly in the following periods. Rather than selling illiquid assets at fire-sale prices, the money market fund could wait for its holdings to mature and avoid this fire-sale discount (which provides the incentive for late redeemers to redeem early). On the other hand, rebuilding its liquidity slowly could increase the probability of a run in the following periods. Zeng (2016) suggests that, when shareholders have a higher propensity to run, the fund should employ a more rapid cash rebuilding policy. Given that the potential for runs is stronger in external prime funds, this leads to our next hypothesis:

Hypothesis 3: External money market funds will have a higher minimum level of their liquid asset balances and will adjust their liquidity more quickly toward target levels.

\section{Sample and Descriptive Statistics}

I use SEC regulatory data to construct a dataset of the security holdings of each US money market fund from January 2011 through April 2015 (52 months). Since November 2010, US money market funds have all been required to disclose detailed security-level portfolio holdings to the SEC on a monthly basis. Specifically, five days after month end, funds must disclose their portfolio holdings as of the last business day of the month using a standardized form, N-MFP. This information becomes public after 60 days.

Funds indicate their fund type on form N-MFP. Funds can classify themselves as prime funds, Treasury funds, government/Agency funds, single state funds and other tax-exempt funds. I focus exclusively on prime funds. Like Chernenko and Sunderam (2014), I also exclude feeder funds and variable annuities. The resulting dataset contains 238 prime money market funds.

These detailed holdings data contain information on the identification of the issuer, the security type, any guarantors of the security, securities underlying a repo transaction, as well as the maturity of the security. I use these detailed, security-level holdings data to create a month-fund panel dataset of fund 
holdings. The detailed maturity level data are necessary so that I can construct relevant monthly measures of fund liquidity. Money market funds are now required by the SEC to hold at least $10 \%$ of their portfolio in Daily Liquid Assets and 30\% of their portfolio in Weekly Liquid Assets. A fund that does not meet these thresholds cannot acquire any assets other than Daily Liquid Assets (if it does not meet the $10 \%$ threshold) or Weekly Liquid Assets (if it does not meet the 30\% threshold). Motivated by these regulatory requirements, I construct the following three fund liquidity metrics:

- Overnight Liquidity: This metric measures the proportion of the value of the fund's portfolio that is invested in securities that mature within one business day. Money market mutual funds often offer settlement of transactions (including payment of cash) on the same day as the transaction. ${ }^{7}$ Thus, funds may view this measure as their primary source of liquidity since they may wish to have securities maturing the next business day, such as repos, that also can be settled should the fund receive redemptions that day. ${ }^{8}$

- Daily Liquidity: Recent SEC rules mandate that money market funds must have Daily Liquidity greater than $10 \%$ of their portfolio. This regulatory metric measures the proportion of the value of the fund's portfolio that is invested in securities that mature within one business day, as well as US Treasuries. US Treasuries and Agency bonds are settled in cash on the following business day ( $\mathrm{T}+1$ basis), so money market funds may also hold Treasuries to provide liquidity in a short time frame but not on a same-day basis. (US Treasuries could provide cash on a same-day basis if used as collateral in a repo transaction, but money market funds typically do not use much leverage.) Trading in a security (rather than holding it to maturity) also entails transaction costs and potential price volatility, albeit small when considering Treasuries. Thus, money market funds may have a preference for Overnight Liquidity over Daily Liquidity.

- Weekly Liquidity: Recent SEC rules mandate that funds hold a minimum of Weekly Liquidity of $30 \%$ of their portfolio. This regulatory metric measures the proportion of the value of the fund's portfolio that is invested in US Treasuries, securities that mature within five business days, as well as securities maturing within 60 days issued by the following government entities: Federal Home Loan Mortgage Corporation (Freddie Mac), Federal

\footnotetext{
${ }^{7}$ See, for example, https://www.fidelity.com/trading/faqs-about-account\#faq about1.

${ }^{8}$ Repurchase agreements are settled on the same day (Fleming and Garbade, 2003). Money market instruments can also be settled on the maturity date (http://www.dtcc.com/matching-settlement-and-asset-services/settlement/money-market-instrumenttransaction-processing).
} 
Home Loan Bank, Federal National Mortgage Association (Fannie Mae), Federal Farm Credit Banks and Straight-A Funding (student loans).

In addition to these liquidity metrics, I also use this fund-security-month data to create measures of the liquidity, nature and riskiness of the fund's portfolio to include in the fund-month panel dataset. Form N-MFP also requires funds to submit summary information at a share class level on a monthly basis. For each share class, funds must report gross subscriptions (inflows), gross redemptions (outflows), net flows, net assets, the net seven-day yield of the share class, as well as the minimum initial investment. For each fund, I sum each of gross subscriptions, gross redemptions, net flows and net assets to create an equivalent, fund-level measure. I construct a variable, Net Yield, as a net asset-weighted average of the net seven-day yields of the individual share class. I classify a share class as institutional if its minimum initial investment is greater than $\$ 100,000$ or if its fund fees are below 10 basis points (bps) for the entire sample period. $\%$ Institutional represents the proportion of the fund's net assets that are in institutional share classes. Funds also report the seven-day gross yield of the fund's securities at a fund level, which is also included as a variable and used to calculate Fees, the difference between the fund's Gross Yield and Net Yield. All variables in the analysis are winsorized at the $1^{\text {st }}$ and $99^{\text {th }}$ percentiles to eliminate the potential for data entry errors in the N-MFP submissions.

These data are merged with bond and equity fund holdings data from Morningstar. For each bond and equity fund, I identify its money market fund holdings as of December 2010, before the start of the sample period. Each holding is then mapped to the SEC money market fund data using fund name and fund ticker. The total aggregate value of each money market fund's holdings by bond and equity funds in the same family is divided by that money market fund's assets under management as of December 2010. This is done to estimate the proportion of the money market fund that is held by other mutual funds in the same family (Own mutual fund holding \%). External is a dummy variable that is equal to one if less than $20 \%$ of the money market fund is held by other mutual funds in the same family at the beginning of the sample period. ${ }^{9}$ Importantly, External is driven by the organization of the fund family, the size of the fund family relative to the money market fund, and the liquidity needs of funds within the family. The investment by the fund family into the money market fund is likely not driven by the money market fund's liquidity because the investment is measured at the beginning of the sample period, and it is unlikely that the funds in the family decide to use the money market fund based on its anticipated liquidity level.

\footnotetext{
${ }^{9}$ Non-money market mutual fund holdings are available on a quarterly basis and the proportion of fund investors that are other mutual funds in the same family is very persistent. We use the dummy variable approach since the precise level of own family fund ownership may not matter beyond a certain threshold (e.g., $60 \%$ family ownership vs. $80 \%$ family ownership). In the robustness section, we show that the main results are not sensitive to the threshold used, and that the main result still holds when using the continuous measure of the amount of own family fund ownership.
} 
Table 1 reports summary statistics. On average, prime funds maintained Weekly Liquidity and Daily Liquidity well in excess of the regulatory minimums of $30 \%$ and $10 \%$, respectively. The regulatory minimum is not binding for most funds, and several funds hold liquidity well in excess of this minimum, suggesting that costs may be low for holding liquidity. The dispersion in liquidity is both cross-sectional and time series in nature. On average, prime funds held about a quarter of their assets in securities maturing the next business day, but there is a wide range-from $0 \%$ to $81 \%$-in the average Overnight Liquidity of the prime funds (Figure 1). The average Daily Liquidity of the prime funds in my sample ranges from 11\% to $86 \%$, with all funds maintaining enough liquidity on average throughout the sample to meet the regulatory minimum of 10\% (Figure 2). There is also a broad range in prime fund Weekly Liquidity (Figure 3), and all funds have had enough Weekly Liquidity on average to meet the minimum $30 \%$ requirement. Over time, the variability of these prime fund liquidity measures is less pronounced and mostly driven by variations in Overnight Liquidity (Figure 4). There was a small increase in average liquidity in the summer of 2011, around the time of the European sovereign debt crisis (Chernenko and Sunderam, 2014). On average, prime funds earned an average gross yield just over 20 bps which, after deducting fees, yielded their investors an average net yield of 4 bps.

Money market funds have a mix of institutional and retail investors (41\% institutional). Internal funds, on average, have about $45 \%$ of their shareholder base from other funds within their fund family, whereas external funds have less than 1\% (Panels B and C). The descriptive statistics also show that internal money market funds tend to hold more liquidity than external funds, and internal funds are more likely to be institutional funds than external funds. Nonetheless, there is heterogeneity in both types of funds; on average almost $40 \%$ of external fund share classes are institutional and internal funds have almost $75 \%$ institutional investors. Non-family mutual funds may be investing in these external funds, as well as large financial and non-financial clients. This heterogeneity can allow us to measure the impact of the externality of a fund while controlling for whether it is an institutional or retail fund. On average, given that internal funds are more likely to be institutional funds, internal funds are also slightly larger, have lower fees, and have a higher turnover than external money market funds. Based on these characteristics alone, internal funds may need to hold more liquidity. We control for these characteristics in our regression analysis, and match on these characteristics in our robustness tests.

Most of the correlations between the variables in our analysis are less than 0.30 (Table 2). However, there are some exceptions. Overnight Liquidity, Daily Liquidity and Weekly Liquidity all have correlations above 0.60 . This is expected since, by construction, Overnight Liquidity is a component of Daily Liquidity, and Daily Liquidity is a component of Weekly Liquidity. These three measures are all negatively correlated with the two maturity measures. This is a mechanical relationship, since there is a 
limit on the maturity of individual assets it can hold, and investing significantly in short-term assets will pull down a fund's average maturity levels. Large funds and institutional funds have a higher turnover, with correlations of 0.46 and 0.43 , respectively. This relationship is well-documented in the literature (e.g., McCabe, 2010; Schmidt, Timmerman and Wermers, 2016).

\section{Estimation method and results}

\subsection{Do money market funds hold more liquidity to protect against runs?}

Hypothesis 1 suggests that external money market funds will hold more liquidity than internal money market funds, since strategic complementarities are stronger when there are more investors from outside the fund family. To test this hypothesis, fund liquidity is regressed against a measure of strategic complementarities, External, as well as control variables motivated by the transactions cost motive for holding liquidity. ${ }^{10}$

I use the three measures of liquidity explained in the previous section: Weekly Liquidity, Daily Liquidity and Overnight Liquidity. The first two measures are regulatory measures, while the third, Overnight Liquidity, represents the most liquid assets of a money market fund, namely those investments maturing on the next business day. I expect the results to be strongest for this measure. A multivariate analysis is performed using a monthly panel regression with each of the liquidity metrics as the dependent variable, with standard errors clustered by both time period and fund. The baseline specification is:

$$
\begin{aligned}
& \text { Liquidity } \left._{i t}=\alpha+\beta_{1} \text { External }_{i}+\beta_{2} \text { Maturity }_{i t-1}+\beta_{3} \text { Ln }_{\text {AUM }}\right)_{i t-1} \\
& +\beta_{4} \text { Institutional }_{i t-1}+\beta_{5} \text { Turnover }_{i t-1} \\
& +\beta_{6} \text { TED Spread }_{t}+\beta_{7} \text { Net Flows }_{i t} \\
& +\beta_{8} \text { I-Year Spread }_{t}+\beta_{9} \text { Leverage }_{i t-1}+\varepsilon_{i t .}
\end{aligned}
$$

The main variable of interest is External, which is a dummy variable indicating whether less than $20 \%$ of the money market fund's investors are family mutual funds. According to the first hypothesis, these funds have more strategic complementarities and should hold more cash. This is because they do not have a single big investor, which can reduce strategic complementarities, and because they do not have other funds in the family as investors who could coordinate to provide liquidity when other investors are withdrawing (Bhattacharya, Lee and Pool, 2013). In Section 2, I described how a fund's liquidity position

\footnotetext{
${ }^{10}$ The analysis uses pooled OLS regressions with standard errors that are clustered at the fund level. In the robustness section, this paper shows that the results are similar whether one uses random effects panel regressions or cross-sectional regressions that use fund-level averages over the sample period. Since the variable of interest, External, is not time-varying, fixed effect regressions are not used.
} 
is the result of a trade-off of the benefits of holding liquidity (to minimize transaction costs) against the opportunity cost of holding too much liquidity. Money market funds holding proportionately more illiquid assets with higher transaction costs should, all else equal, hold more liquidity. The first set of variables, Maturity, Leverage and $\operatorname{Ln}(A U M)$ are included as measures of the liquidity of the fund's portfolio. Maturity is a measure of illiquidity, given that it represents the immediacy with which the portfolio can be converted to cash without selling underlying securities. As its name suggests, Maturity is equal to the weighted average portfolio maturity of the fund's holdings, excluding those assets that mature on the next business day. Leverage is measured as the sum of fund liabilities and net assets, divided by the fund's net assets. Finally, $\operatorname{Ln}(A U M)$ is the logarithm of the fund's assets under management and is included to control for economies of scale. All else equal, larger funds could face lower transaction costs because of access to better trading technology and diversification of investor flows, and may have less need to hold cash for transactions purposes. However, they may hold more liquidity because transaction costs are convex in transaction size (Massa and Phalippou, 2005) or because they are more likely to internalize the price impact their asset sales have on the market (Chernenko and Sunderam, 2015).

Funds with higher volatility of investor flows should, according to the transaction costs trade-off, hold a higher level of liquidity. I include several variables to capture characteristics of the fund's investor base. \% Institutional, which measures the proportion of the fund's assets in institutional share classes, is included since outflows during the last crisis were concentrated in funds held by institutional investors. Turnover is the minimum of monthly subscriptions and redemptions, scaled by the previous month's assets under management. Because I use the minimum, it is not affected by investor net flows. All else equal, a higher value of this measure should be associated with more volatile flows and a fund should require a higher liquidity buffer if it receives more flows (in both directions) during the month. The TED spread (three-month US dollar LIBOR less three-month US Treasury bill yield) is a measure of flight to quality and as such could be an indicator of future fund redemptions. Net Flows within the current period will result in an increase in the fund's liquidity at the end of the period if the fund does not decide to invest all of its new inflows in illiquid assets (or if it does not use its liquid assets to fully meet fund outflows). Finally, the 1 Year Treasury Spread to the Federal Funds rate is included to account for the opportunity cost of liquidity. During periods when this spread is high, the opportunity cost of investing in short-term (overnight) liquid assets is higher and funds should thus hold less liquidity.

After controlling for transaction cost explanations for liquid asset holdings, external prime money market funds hold more overnight liquidity than internal prime money market funds (Table 3, two rightmost columns). The coefficient on the main variable of interest, External, is a statistically significant 0.112 , indicating that these funds hold almost $11 \%$ more of their portfolio in overnight liquidity, their most 
liquid asset holding. This is economically significant: it is slightly larger than the amount of Daily Liquidity that funds are required by the SEC to hold. In the rightmost column, the analysis includes time dummies and the in-sample standard deviation of fund flows, $\sigma^{\text {Flows }}$, as a measure of flow volatility. This measure has the drawback that it includes the full sample rather than just the data available at the time, and so may include some look-ahead bias. Nonetheless, it is encouraging that the coefficients on External do not change much when including this alternative definition of fund liquidity along with fixed time effects. The results are weaker for the two regulatory definitions of liquidity, Weekly Liquidity and Daily Liquidity. In general, prime money market funds hold more liquidity than is required by the SEC and the presence of strategic complementarities does not seem to affect their regulatory liquidity holdings.

Coefficients on the control variables are consistent with the transactions cost explanation for holding liquidity and are, for the most part, strongest for Overnight Liquidity. Funds with more illiquid assets hold more Daily Liquidity and Overnight Liquidity, given the positive, statistically significant coefficient on Maturity. Larger funds have lower liquidity. This is in contrast to the findings for non-money market mutual funds (Massa and Phalippou, 2005, for example). However, in larger money market funds, it is possible that transaction costs are not as convex, given that their assets naturally become liquid as they mature, regardless of the size of the fund. Thus, it could be that the larger funds have lower transaction costs because the effect of having more diversified investor flows (lessening the need to hold cash) outweighs the convexity of transaction costs in money market funds.

Fund liquidity also appears to be determined by characteristics of the fund's investor base rather than characteristics of its holdings. For Overnight Liquidity, funds with a higher Turnover and funds with more institutional investors hold more liquid assets. When there is more uncertainty in the market, as measured by a higher TED spread, funds hold more Weekly Liquidity, Daily Liquidity and Overnight Liquidity. When the TED spread is high, the opportunity cost of holding liquidity (in the form of government securities) is also higher. However, this would predict that funds hold less liquidity, rather than more liquidity. Thus, it appears that the increase in uncertainty associated with a TED spread increase has a much stronger effect on fund liquidity than that of the increased opportunity cost represented by a higher spread. Daily Liquidity and Overnight Liquidity also increase following net flows, suggesting that funds do not fully invest concurrent flows. This is consistent with funds allowing their liquidity to fluctuate within a range to minimize transaction costs. Across most specifications, there is a statistically significant negative coefficient on 1 Year Spread: when longer-term rates are higher, funds hold less liquidity. This is consistent with the notion that funds hold less liquidity when the opportunity cost of doing so is high. 


\subsection{How do funds respond to quarter-end effects?}

Munyan (2015) documents a substantial reduction in the repo financing of non-US bank dealers at quarter end, due to window-dressing incentives caused by differences in the implementation of Basel III regulations. According to Hypothesis 2, money market funds should reduce their Overnight Liquidity at quarter ends as non-US bank dealers have a reduced appetite for overnight repo financing. Given that external funds should be more concerned about strategic complementarities, the hypothesis suggests that these funds will not reduce their liquidity as much as internal funds. Further, the implementation of the Federal Reserve's Overnight Reverse Repo Facility in September 2013 should mitigate these quarter-end effects since money market funds can use this facility as a source of Overnight Liquidity at quarter ends. The analysis uses a fixed effect regression since the hypothesis is concerned with the interaction effect of External with quarter ends, and thus the estimation of the effect of the time-invariant variable External on the level of liquidity is not important in this context:

$$
\begin{aligned}
&\text { Liquidity } \left._{i t}=\alpha+\beta_{1} \text { Maturity }_{i t-1}+\beta_{2} \text { Ln}_{(A U M}\right)_{i t-1} \\
&+\beta_{3} \text { Institutional }_{i t-1}+\beta_{4} \text { Turnover }_{i t-1} \\
&+\beta_{5} \text { TED Spread }_{t}+\beta_{6} \text { Net Flows }_{i t} \\
&+\beta_{7} \text { I Year Spread }_{t}+\beta_{8} \text { Leverage }_{i t-1} \\
&+\beta_{9} \text { ORRP }_{t}+\beta_{10} \text { Quarter }_{t}+\beta_{11} \text { Quarter }_{t} * \text { External }_{i} \\
&+\beta_{12} \text { ORRP }_{t} * \text { External }_{i} \\
&+\beta_{13} \text { ORRP }_{t} * \text { External }_{i} * \text { Quarter }_{t}+\mu_{\mathrm{i}}+\varepsilon_{\mathrm{it} .}
\end{aligned}
$$

In this regression, ORRP is a dummy variable that takes a value of one after September 2013, when the Federal Reserve began implementing the Overnight Reverse Repo Facility. Quarter is a dummy variable that takes the value of one on the four calendar quarter-end months: March, June, September and December. With Overnight Liquidity, Hypothesis 2 would predict a negative coefficient on Quarter and a positive coefficient on the interaction between Quarter and External. The coefficient on the interaction between ORRP and Quarter should be positive, if the Overnight Reverse Repo Facility alleviates the reduced repo activity from bank dealers.

My results are presented in Table 4 and are consistent with the hypothesis. There is a significant reduction in Overnight Liquidity on quarter-end months (Quarter coeff. $=-0.020$, t-stat $=4.56$ ). This effect is almost fully mitigated after the Federal Reserve implements its Overnight Reverse Repo Facility (ORRP 
* Quarter coeff. $=0.017, \mathrm{t}$-stat $=2.03)$. Consistent with Munyan $(2015)$, this suggests that window-dressing behavior of non-US bank dealers resulted in a reduction in money market fund liquidity at quarter ends. Given that Daily Liquidity and Weekly Liquidity do not change at quarter ends, this suggests that the money market funds are replacing the reduction in repo with Treasuries and short-term Agency securities. Hypothesis 2 is most concerned with how strategic complementarities influence how a money market fund reacts to this quarter-end withdrawal of cash demand from the bank dealers. The results in Table 4 suggest that internal funds reduce their Overnight Liquidity by twice as much as the external funds, given the statistically significant, positive coefficient on External * Quarter. Internal funds reduce their Overnight Liquidity by $2 \%$ at quarter ends, while external funds reduce their Overnight Liquidity by $1.1 \%(-0.020+$ 0.009). This is particularly striking given that internal funds are reducing their Overnight Liquidity levels from a much lower base, given the results in Table 3. Also supporting this hypothesis, there is almost no difference between the two types of funds after the introduction of the Overnight Reverse Repo Facility, which provided an alternate destination for money market fund cash following the reduction in cash demand from the bank dealers. Internal funds' Overnight Liquidity was essentially unchanged at quarter ends postORRP as it fell by only $0.003 \%(-0.020+0.017)$. External funds' Overnight Liquidity was also essentially unchanged as it increased by only $0.001 \%(-0.020+0.017+0.009-0.005)$. The results also hold once you include fixed time effects in addition to fixed fund effects.

There is no effect on Daily Liquidity or Weekly Liquidity, since the non-US bank dealers' reduction in overnight repos should only have a direct effect on money market funds' Overnight Liquidity. That is, although Overnight Liquidity is a component of the other two liquidity metrics, the effect should be dampened because these two metrics include other liquidity sources (e.g., Treasuries). Also, the dealers typically use US Treasuries and Agency securities as collateral for their repo positions, so as dealers reduce their repo positions, they also may be selling the underlying collateral. Consistent with this prediction, Munyan (2015) uses TRACE data to show that dealers do sell Agency bonds leading up to quarter ends. Therefore, the reduction in repo cash demand from dealers may also be accompanied by a decrease in their holdings of US Treasuries and Agency securities. Also, since Daily Liquidity and Weekly Liquidity include short-term Treasuries and Agency securities in their respective definitions, the effect of a reduction in repo should be muted.

\subsection{Is a fund's dynamic adjustment of liquidity affected by strategic complementarities?}

If funds manage their liquidity to trade off the benefits of holding extra liquidity against the costs of liquidity, funds that have large liquidity ratio ranges (i.e., higher maximum liquidity above a minimum liquidity threshold) should have higher volatility, higher transaction costs associated with adjusting 
liquidity, and a lower opportunity cost of holding liquidity (Miller and Orr, 1966). ${ }^{11}$ Since it is more costly for funds with higher transaction costs to adjust their liquidity, all else equal, they should allow their liquidity ratio to deviate more from target before transacting to bring the ratio back to target. Small funds and funds that invest in relatively more illiquid assets (e.g., European banks and longer-maturity assets) are thus expected to be associated with a wider liquidity range. Similarly, funds with more volatile cash flows (due to volatility of investor flows or volatility of investments) should, all else equal, have a higher liquidity ratio, and allow a larger range (lower minimum and high maximum) of liquidity to avoid transacting too frequently. Finally, funds that have a higher wedge between the cost of liquid assets and less liquid assets should have a smaller range of liquidity ratio, given that this entails a greater cost of deviating from target liquidity and thus suggests they should be more active in adjusting liquidity toward target.

In addition, funds may be concerned about the impact of low fund liquidity on the potential for runs and will have a tighter liquidity range to limit the signaling impact of low liquidity (Hypothesis 3 ). Strategic complementarities should also impact how funds narrow their liquidity range. Intuitively, if a fund is concerned about the negative signaling effect of low liquidity levels, it will have a narrower range by increasing the minimum level of liquidity of its fund. In contrast, if it decreases its range by lowering the maximum it allows its fund liquidity to achieve, the narrow range is more likely to be driven by effects other than strategic complementarities. For example, in their model, Liu and Mello (2011) assume that there is no coordination problem once fund liquidity exceeds a certain threshold, which would suggest that there is no benefit in having a higher maximum liquidity level to prevent coordination problems. In particular, I run the following regression of the in-sample minimum and maximum liquidity for each prime money market fund against External, as well as the sample average of size $(\operatorname{Ln}(A U M))$, \% Long Maturity, Gross Yield, \%Institutional and Turnover, along with the sample standard deviation of Net Flows and Gross Yields:

$$
\begin{aligned}
& \text { Minimum Liquidity }_{i}=\alpha+\beta_{1} \operatorname{Ln}(\text { AUM })_{i}+\beta_{2} \text { Maturity }_{i}+\beta_{3} \sigma_{\text {Gross Yield }_{i}} \\
& +\beta_{4} \text { Gross Yield }_{i} \text { Institutional }_{i t-1}+\beta_{5} \sigma^{\text {Flows }_{i}} \\
& +\beta_{6} \text { Turnover }_{i}+\beta_{7} \text { External }_{i}+\beta_{8} \text { oInstitutional }_{I}+\varepsilon_{\mathrm{i} .}
\end{aligned}
$$

Overall, the results are consistent with funds trading off the costs and benefits of liquidity. Larger funds, assumed to represent funds with lower transaction costs, have a narrower range of Weekly Liquidity, Daily Liquidity and Overnight Liquidity.

\footnotetext{
${ }^{11}$ Fischer, Heinkel and Zechner (1989) develop a dynamic model of capital structure choice and make similar predictions about how the range of capital structure decisions relates to the tax benefits of debt, the variance of underlying asset value, firm size and bankruptcy costs.
} 
In Table 5, several measures increase the portfolio maximum liquidity but have minimal impact on the minimum liquidity level. Consistent with the theory that funds trade off the transaction costs of holding illiquid assets against the reduced yield from holding liquid assets, the standard deviation of Net Flows and Gross Yields is associated with a higher in-sample maximum of all three liquidity metrics, but has no impact on the in-sample minimum. With more volatility, fund managers want to avoid the transaction costs of frequently rebalancing their fund's liquidity ratio, and so will likely let their liquidity fluctuate more (and absorb the lower yield on liquid assets) rather than pay the transaction costs to keep liquidity in a tighter range. Funds that have a higher mean Gross Yield have a lower maximum liquidity measure (Columns 2, 4 and 6). Again, a higher gross yield on their portfolio is consistent with a higher opportunity cost of holding illiquid assets, so funds should be more reluctant to have higher liquid asset balances. Conversely, their minimum balances may be driven more by regulatory requirements and concern over strategic complementarities, so they may have less scope to move their minimum balances for transaction costs reasons (in the classic Miller-Orr model, the minimum cash balance is assumed to be zero and the range is driven by the maximum liquidity amount).

The results suggest that prime funds maintain higher minimum liquid asset balances when they are concerned about the potential for strategic complementarities in the investor redemption decision. For Daily Liquidity and Overnight Liquidity, the coefficient on External is positive and statistically significant and implies that these funds hold about 5\% to $7 \%$ more of their assets in Daily Liquidity and Overnight Liquidity. These funds, which have an investor base that may be more likely to run, may be concerned about liquidity ratios approaching their regulatory minimums. External funds also have a higher maximum Overnight Liquidity, which should have much smaller impact on the likelihood of an investor run. Funds catering to institutional investors also maintained a higher minimum level of liquidity, which is consistent with more concerns about strategic complementarities, since institutional prime funds experienced investor runs during the financial crisis (McCabe, 2010). Nonetheless, external funds maintained a higher minimum level of liquidity after controlling for the institutional nature of their investor base, suggesting that the specific nature of their investors (own family funds vs. external investors) matters.

Money market funds' speed of adjustment towards target liquidity may also be impacted over concerns for runs. These funds face a trade-off in that having a lower speed of adjustment towards target may minimize transaction costs of returning liquidity to target and reduce the incentives for investors to run in the current period. However, this lower adjustment speed may create incentives for investors to run in the following period if fund liquidity is too low (Zeng, 2016). Funds' speed of adjustment is estimated using a dynamic panel regression, including fixed fund effects. This technique has also been widely used in the literature on a firm's adjustment towards a target capital structure (e.g., Flannery and Rangan, 2006, 
Frank and Goyal, 2009, Huang and Ritter, 2009, Leary and Roberts, 2005). ${ }^{12}$ Trading off the costs and benefits of holding liquid assets, a fund will steer its liquidity towards a target liquidity ratio. This ratio will likely vary over time given investor flows, portfolio changes, as well as changes in market conditions that affect the costs and benefits of holding liquidity. The next period's target liquidity ratio (Liquidity ${ }_{i t+1}$ ) can be described as a (linear) function of fund characteristics, $\mathrm{X}_{\mathrm{it}}$, that relate to the costs and benefits of holding liquidity assets:

$$
\text { Liquidity }^{*}{ }_{i t+1}=\beta X_{i t}
$$

Given the transaction costs associated with adjusting a fund's portfolio, a fund will not always be at its target liquidity ratio. In practice, a fund may only adjust a proportion of the deviation of its current liquidity from its target liquidity ratio:

$$
\text { Liquidity }_{i t+1}-\text { Liquidity }_{i t}=\lambda\left(\text { Liquidity }_{i t+1}-\text { Liquidity }_{i t}\right)+\varepsilon_{\mathrm{it}+1}
$$

The speed of adjustment, $\lambda$, reflects both transaction costs for buying and selling the less liquid assets, as well as costs associated with transactions in its liquid asset portfolio. By definition, liquid assets should have minimal transaction costs. However, this may depend upon the exact measure of liquidity being used. This paper examines three potential measures of fund liquidity (described in Section 3). A more empirically accurate measure of money market fund liquidity should be associated with a higher speed of adjustment, since this suggests that the fund cares more about returning toward its target liquidity level or that the measure represents a more liquid asset with smaller transaction costs. The speed of adjustment can be empirically estimated by substituting in equation (4) and then rearranging equation (5):

$$
\text { Liquidity }_{i t+1}=\lambda \beta X_{i t}+(1-\lambda) \text { Liquidity }_{i t}+\varepsilon_{\mathrm{it}+1}
$$

This setup assumes that all funds adjust towards their target liquidity ratio at the same speed, and that this adjustment occurs in a smooth fashion. However, money market funds may only decide to adjust their liquidity once it approaches the bounds of their optimal liquidity range, and hence may make infrequent adjustments. Nonetheless, Flannery and Rangan (2006) estimate a partial adjustment model on simulated capital structure data assuming infrequent adjustments, and find that the partial adjustment model is a reasonable approximation of the speed of adjustment even when leverage changes are lumpy. Thus, lumpy adjustment by money market funds should not have a first-order impact on their estimated speed of adjustment.

\footnotetext{
${ }^{12}$ More recent literature has suggested using the Blundell and Bond (1998) System GMM estimation method (e.g., Flannery and Hankins, 2011; Faulkender et al, 2012). In the Robustness section, I show that there are small differences between the Fixed Effect estimator and the System GMM estimator.
} 
Table 6 reports the results of the fixed effect regression for each of the three different measures of liquidity for prime money market funds. The speeds of adjustment for internal funds range from $32.2 \%$ (=10.678 ) for Weekly Liquidity to $76.6 \%$ (=1-0.234) for Overnight Liquidity. Thus, internal funds are able to eliminate more than three quarters of their Overnight Liquidity gap over the course of a month. This measure consists entirely of assets maturing the next business day, and a high speed of adjustment is consistent with minimum transaction costs for buying or selling these assets. If a fund wants to increase its Overnight Liquidity, it could simply invest in an overnight asset such as a repo instead of a more illiquid asset, such as commercial paper. Overnight Liquidity is not fully eliminated over the course of the month since funds may not have a single, optimal level of liquidity, but rather may have a range of liquidity over which they are indifferent. The two regulatory measures of liquidity, Daily Liquidity and Weekly Liquidity, both have an adjustment speed under 35\%. These two measures contain liquid securities, such as Treasuries and Agencies. Even though these assets are liquid, there are still some transaction costs associated with selling Treasuries, whereas there are none associated with liquidating an investment that naturally matures the next day. Overall, the results suggest that money market funds use assets maturing the next business day (e.g., overnight repos) as their most immediate source of liquidity.

A fund's ability to adjust towards target depends upon investor flows. If a fund is below its target liquidity and receives net inflows during the month, it is easier for it to adjust towards target. Alternatively, if liquidity is already above target, these fund inflows would bring the fund further away from its target level of liquidity. There is a positive, statistically significant coefficient on concurrent net flows in prime funds. The coefficients on concurrent net flows range from 0.09 to 0.13 , suggesting that, when a money market fund receives net flows, its illiquidity ratio will increase by an additional $9 \%$ to $13 \%$ of these net flows. The rest is invested proportionally into its more illiquid assets. Weekly Liquidity responds least to fund flows and, consistent with the results on the speed of adjustment, does not seem to be used as a money market fund's first source of liquidity. Again, this is consistent with funds preferring assets maturing overnight to meet their short-term liquidity needs. Most of the other explanatory variables are not statistically significant. This is a result of the fixed fund effects, and suggests that the fund's target liquidity ratio is relatively stable over time.

To further investigate Hypothesis 3, Table 5 includes an interaction between the External dummy variable and the lagged liquidity measures. If strategic complementarities are important and external prime funds adjust more quickly back to target, this coefficient should be negative. Indeed, external prime money market funds adjust Daily Liquidity more quickly back towards the target level of liquidity than do internal funds. This is consistent with the results examining liquidity ranges, and could be an indication that funds with greater potential for runs are more active in managing their liquidity. In contrast, the Overnight Liquidity speed of adjustment is slower in external funds than in internal funds (but still quicker than the 
Daily Liquidity speed of adjustment in external funds). It may be that, since their Overnight Liquidity is much lower than that of external funds, internal funds more carefully manage Overnight Liquidity.

\section{Robustness Tests}

In the previous analysis, external funds were defined as those that had less than $20 \%$ of their shareholder base as other mutual funds in the same family. The results are robust to other thresholds used to define external funds (Table 7). Lowering the threshold increases the number of internal funds, but decreases the strength of the result, as theory would suggest: Chen, Goldstein and Jiang (2010) propose that strategic complementarities are weaker as the size of the largest investor grows. For Overnight Liquidity, external prime funds, defined as those with less than $10 \%$ or less than $5 \%$ mutual fund investors from the same family, have about $6 \%$ more Overnight Liquidity than internal prime funds. This is still an economically significant amount-more than half the regulatory minimum requirement for Daily Liquidity - but is about half the difference when comparing with external funds with more than $20 \%$ of their shareholder base in the same family.

Finally, rather than using a dummy variable External to measure strategic complementarities, they could be measured directly using the proportion of each prime money market fund's investors that are other mutual funds. Again, there is a statistically significant, negative relationship between prime fund Overnight Liquidity and this measure, suggesting that those funds that are used more as a cash management vehicle for other mutual funds within the family hold less of their main source of liquidity. There could be a concern that our results are driven by the fact that mutual funds are institutional investors. However, institutional investors should require more liquidity, not less, given that they behave more like "hot money" (Schmidt, Timmerman and Wermers, 2016). The variable \% Institutional should control for this, and its sign is consistent with this effect. Mutual funds are a subset of institutional investors and it could nevertheless be the case that mutual funds do not have a high propensity to redeem from the money market funds they invest in, and, as such, these money market funds may not need to hold as much liquidity. To rule out this possibility, the regression in the rightmost column of Table 7 includes the variable, Other mutual fund holding \%. This variable measures the proportion of a money market fund's shareholder base that includes mutual funds that are not in the same fund family. If funds hold more liquidity because their shareholder base includes mutual funds, the coefficient on this variable should be negative. This is not the case; therefore, it seems unlikely that it is the mutual fund shareholder base driving the result and more likely that it is the same family mutual fund shareholder base driving the result.

Using other econometric methods, the coefficient on External remains positive and statistically significant, maintaining support for the hypothesis that these money market funds hold more liquidity 
because of strategic complementarities. So far, I have used OLS regressions to estimate the determinants of money market fund liquidity. Unfortunately, fixed effect regressions are not feasible given the data, since the variable of interest, External, is fixed. Table 8 presents regressions for Overnight Liquidity using four other estimation methods: pooled OLS with fund-clustered standard errors, random effects, population average and Fama-MacBeth regressions. The main analysis clusters standard errors by both time and fund and should thus generally be more conservative than clustering only by fund. However, if the number of clusters in one dimension is small (i.e., < 50), it may be more appropriate to not cluster on that dimension (Cameron and Miller, 2013). In my setup, the 52 time periods are close to the threshold, so it is not clear a priori which method is more appropriate. The standard errors do not change much when clustering only on one dimension instead of two, suggesting the number of time clusters is not too small. Efficiency could also be improved by estimating a random effects model (Petersen, 2009). Column 3 shows that our coefficient of interest, External, has the same magnitude but a smaller standard error using this approach. The last column performs Fama-MacBeth regressions of Overnight Liquidity on the same covariates. In these regressions, the results are similar, but the $t$-statistics are much larger, given that Fama-MacBeth produces downward-biased standard errors when regressing a persistent fund characteristic on other persistent fund characteristics (Petersen, 2009).

Table 9 suggests that the results are similar when matching internal money market funds to external money market funds. The summary statistics in Table 1 highlight several differences between internal and external money market funds. Internal funds are larger, have a higher turnover, and have a greater proportion of institutional investors in their investor base. My analysis (e.g., Table 3) includes covariates to control for these and other differences between the funds. Nonetheless, these covariates could have nonlinear effects on fund liquidity. To address this potential criticism, I match each internal fund to a corresponding external fund (with replacement) based on propensity scores derived from a probit model incorporating Ln (AUM), Turnover and \% Institutional, and examine the average Overnight Liquidity of each of these funds. The Average Treatment Effect (ATE) and the Average Treatment Effect for the Treated (ATET) are both larger than the estimates reported earlier: external funds hold about $14 \%$ more of their portfolio in Overnight Liquidity than do internal funds. This result is robust to different matching methods. It is very similar if matching each internal fund to its three nearest neighbors. It is also robust to matching using Mahalanobis (1936) distance rather than propensity scores.

\section{Concluding Remarks}

Money market funds must maintain a minimum level of liquidity as a buffer against shareholder redemptions as well as to meet regulatory requirements. There is wide variation in money market fund 
liquidity despite the fact that money market funds are relatively homogeneous given regulatory constraints on their portfolio holdings and given minimum requirements for fund liquidity. The results in this paper suggest that some of this difference is due to differences in the funds' investors. Some funds have investors that have more strategic complementarities among themselves, meaning that they may be more likely to run when the fund is hit with a negative shock. Given this potential for shareholder runs, funds with investors more likely to run should hold more liquidity, to both reduce the transaction costs associated with shareholder redemptions, and to decrease the likelihood of a run (Liu and Mello, 2011).

The main finding in this paper is that external prime funds hold more Overnight Liquidity than internal prime funds (e.g., those funds that are money market funds for others within the fund family), which may be because external funds are more vulnerable to investor runs. The difference in Overnight Liquidity between external and internal funds is economically large-equivalent to $11 \%$ of their portfolio assets - even after controlling for fund characteristics that can explain fund liquidity. For example, funds with a more volatile investor base, more leverage, longer-maturity assets and institutional shareholders tend to hold a higher level of liquidity.

Munyan (2015) finds that non-US bank dealers reduce their repo activity at quarter ends, and this exogenous reduction in cash demand reduces money market fund liquidity. I find that external money market funds respond to this reduction in cash demand differently. They do not let their Overnight Liquidity drop as much as internal funds do. Again, since external funds have more strategic complementarities among their shareholders, this suggests that these funds hold more liquidity because of a greater susceptibility to runs. 
Appendix A. Variable descriptions

\begin{tabular}{|c|c|}
\hline$\%$ Institutional & $\begin{array}{l}\text { This variable measures the proportion of the fund's assets that are in institutional share classes } \\
\text { (those with a minimum investment of at least } \$ 100,000 \text { ). }\end{array}$ \\
\hline Average Life Maturity & $\begin{array}{l}\text { The dollar-weighted average maturity of the fund's portfolio holdings without regard to interest } \\
\text { rate reset dates. }\end{array}$ \\
\hline $\begin{array}{l}\text { Average Portfolio } \\
\text { Maturity }\end{array}$ & $\begin{array}{l}\text { The dollar-weighted average maturity of the fund's portfolio holdings. It considers the maturity } \\
\text { of longer-term floating or variable-rate securities to be the earliest interest rate reset date. }\end{array}$ \\
\hline Daily Liquidity & $\begin{array}{l}\text { This variable measures the proportion of the value of the fund's portfolio that is invested in US } \\
\text { Treasuries and securities that mature within one business day. }\end{array}$ \\
\hline External & $\begin{array}{l}\text { A dummy variable that is equal to one if less than } 20 \% \text { of the money market fund is held by } \\
\text { other mutual funds in the same family at the beginning of the sample period (i.e., Own mutual } \\
\text { fund holding } \%<0.20 \text { ) }\end{array}$ \\
\hline Fees & This variable is equal to the difference between Gross Yields and Net Yields. \\
\hline Gross Yield & $\begin{array}{l}\text { This variable is equal to the current seven-day yield, as reported by the fund in SEC form } \\
\text { N-MFP. }\end{array}$ \\
\hline Leverage & $\begin{array}{l}\text { This variable is calculated as the sum of fund liabilities and net assets, divided by the fund's net } \\
\text { assets. }\end{array}$ \\
\hline Ln (AUM) & $\begin{array}{l}\text { The logarithm of the fund's assets under management (total value of Available for Sale } \\
\text { Securities). }\end{array}$ \\
\hline Maturity & $\begin{array}{l}\text { This variable is equal to the weighted average portfolio maturity of the fund's holdings, } \\
\text { excluding those assets that mature on the next business day. }\end{array}$ \\
\hline Net Flows & $\begin{array}{l}\text { Net monthly flows of the fund, expressed as a percentage of the previous month's assets under } \\
\text { management. }\end{array}$ \\
\hline Net Yield & $\begin{array}{l}\text { This variable is equal to the seven-day net yield of the fund (i.e., gross yield less expenses), } \\
\text { which funds must report for each share class of the fund in form N-MFP. The net yield of the } \\
\text { fund is calculated as the asset-weighted average of the net yield of the individual share classes } \\
\text { of the fund. }\end{array}$ \\
\hline $\begin{array}{l}\text { Other mutual fund holding } \\
\%\end{array}$ & $\begin{array}{l}\text { This variable estimates the proportion of the money market fund that is held by other mutual } \\
\text { funds that are not in the same family. It is equal to the total aggregate value of each money } \\
\text { market fund's holdings by bond and equity funds that are not in the same family, divided by } \\
\text { that money market fund's assets under management as of December } 2010 \text {. }\end{array}$ \\
\hline Overnight Liquidity & $\begin{array}{l}\text { This variable measures the proportion of the fund's portfolio that is invested in assets maturing } \\
\text { on or before the next business day. }\end{array}$ \\
\hline $\begin{array}{l}\text { Own mutual fund holding } \\
\%\end{array}$ & $\begin{array}{l}\text { This variable estimates the proportion of the money market fund that is held by other mutual } \\
\text { funds in the same family. It is equal to the total aggregate value of each money market fund's } \\
\text { holdings by bond and equity funds in the same family, divided by that money market fund's } \\
\text { assets under management as of December } 2010 \text {. }\end{array}$ \\
\hline ORRP & $\begin{array}{l}\text { A dummy variable that takes a value of one after September 2013, when the Federal Reserve } \\
\text { began implement the Overnight Reverse Repo Facility. }\end{array}$ \\
\hline Quarter & $\begin{array}{l}\text { A dummy variable that takes the value of one of the four calendar quarter-end months: March, } \\
\text { June, September and December. }\end{array}$ \\
\hline Treasury Liquidity & $\begin{array}{l}\text { This variable represents the proportion of the fund's portfolio invested in securities issued } \\
\text { directly by the US government. }\end{array}$ \\
\hline Turnover & $\begin{array}{l}\text { This variable is equal to the minimum of a fund's monthly redemptions and subscriptions, } \\
\text { expressed as a percentage of the previous month's assets under management. }\end{array}$ \\
\hline Weekly Liquidity & $\begin{array}{l}\text { This metric measures the proportion of the value of the fund's portfolio that is invested in US } \\
\text { Treasuries, securities that mature within five business days, as well as securities maturing } \\
\text { within } 60 \text { days issued by the following government entities: Federal Home Loan Mortgage } \\
\text { Corporation (Freddie Mac), Federal Home Loan Bank, Federal National Mortgage Association } \\
\text { (Fannie Mae), Federal Farm Credit Banks and Straight-A Funding (student loans). }\end{array}$ \\
\hline
\end{tabular}




\section{References}

Anbil, S., Senyuz, Z., 2016. Window-dressing and trading relationships in the tri-party repo market. Working paper.

Amihud, Y, Mendelson, H., 1986. Asset pricing and the bid-ask spread. Journal of Financial Economics 17 (2), 223-249.

Ben-Raphael, A., 2014. Flight-to-liquidity, market uncertainty, and the actions of mutual fund investors. Working paper.

Bhattacharya, U., Lee, J.H., Pool, V.K., 2013. Conflicting family values in mutual fund families. Journal of Finance 68 (1), 173-200.

Blundell, R., Bond, S., 1998. Initial conditions and moment restrictions in dynamic panel data models. Journal of Econometrics 87, 115-143.

Bond, S., 2009. Dynamic panel data models: A guide to micro data methods and practice. CEMPA working paper CWP09/02.

Cameron, A.C., Miller, D.L., 2013. A practitioner's guide to cluster-robust inference. Working paper.

Chen, Q., Goldstein, I., Jiang, W., 2010. Payoff complementarities and financial fragility: Evidence from mutual fund outflows. Journal of Financial Economics 97, 239-262.

Chernenko, S., Sunderam, A., 2014. The quiet run of 2011: money market funds and the European debt crisis. Review of Financial Studies 27 (6), 1717-1750.

Chernenko, S., Sunderam, A., 2015. Liquidity transformation in asset management: evidence from the cash holdings of mutual funds. Ohio State University Working Paper.

Christoffersen, S., 2001. Why do money fund managers voluntarily waive their fees? Journal of Finance $56,117-1140$.

Chordia, T., 1996. The structure of mutual fund charges. Journal of Financial Economics 41, 3-39.

Constantinides, G., 1986. Capital market equilibrium with transaction costs. Journal of Political Economy 94 (4), 842-862.

Covitz, D., Downing, C., 2007. Liquidity or credit risk? The determinants of very short-term corporate yield spreads. Journal of Finance 62, 2308-2328.

Diamond, D.W., Dybvig, P.H., 1983. Bank runs, deposit insurance, and liquidity. Journal of Political Economy 91, 401-419.

Dubofsky, D.A., 2010. Mutual fund portfolio trading and investor flow. Journal of Banking and Finance $34,802-812$. 
Edelen, R. M., 1999. Investor flows and the assessed performance of open-end mutual funds. Journal of Financial Economics 53, 439-466.

Elton, E., Gruber, M., Blake, C., Krasny, J., Ozelge, S., 2010. The effect of holdings data frequency on conclusions about mutual fund behavior. Journal of Banking and Finance 34, 912-922.

Fama, E., MacBeth, J., 1973. Risk, return, and equilibrium: empirical tests. Journal of Political Economy 81, 607-636.

Faulkender, M., Flannery, M., Watson Hankins, K., Smith, J., 2012. Cash flows and leverage adjustments. Journal of Financial Economics 103, 632-646.

Financial Stability Board, 2014. Assessment methodologies for identifying non-bank non-insurer global systemically important financial institutions. Consultative document.

Fischer, E., Heinkel, R., Zechner, J., 1989. Dynamic capital structure choice: theory and tests. Journal of Finance 44 (1), 19-40.

Flannery, M., Hankins, K., 2011. Estimating dynamic panels in corporate finance. Unpublished working paper, University of Florida and University of Kentucky.

Flannery, M., Rangan, K., 2006. Partial adjustment toward target capital structures. Journal of Financial Economics 79, 469-506.

Fleming, M., Garbade, K., 2003. The repurchase agreement refined: GCF repo. Federal Reserve Bank of New York Current Issues in Economics and Finance 9 (6).

Frank, M., Goyal, V., 2009. Capital structure decisions: which factors are reliably important? Financial Management 38, 1-37.

Goldstein, I., Pauzner, A., 2005. Demand deposit contracts and the probability of bank runs. Journal of Finance 60, 1293-1328.

Huang, J., 2015. Dynamic liquidity preferences of mutual funds. Working paper.

Huang, R., Ritter, J., 2009. Testing theories of capital structure and estimating the speed of adjustment. Journal of Financial and Quantitative Analysis 44, 237-271.

Investment Company Institute, 2012a. A bad idea: Forcing money market funds to float their NAVs.

Investment Company Institute, 2012b. A bad idea: Redemption freeze for money market funds.

Investment Company Institute, 2016. 2016 Investment Company Institute Fact Book, 29.

Kacperczyk, M., Schnabl, P., 2012. How safe are money market funds? AFA 2012 Chicago Meetings paper.

Leary, M., Roberts, M., 2005. Do firms rebalance their capital structures? Journal of Finance 60, 25752619.

Liu, X., Mello, A., 2011. The fragile capital structure of hedge funds and the limits to arbitrage. Journal of Financial Economics 102 (3), 491-506. 
Mahalanobis, P.C., 1936. On the generalised distance in statistics. Proceedings of the National Institute of Sciences of India, 2 (1): 49-55

Manconi, A., Massa, M., Yasuda, A., 2012. The role of institutional investors in propagating the crisis of 2007-2008. Journal of Financial Economics 104 (3), 491-518.

Malherbe, F., 2014. Self-fulfilling liquidity dry-ups. Journal of Finance 69, 947-970.

Massa, M., Phalippou, L., 2005. Mutual funds and the market for liquidity. Working paper.

McCabe, P., 2010. The cross section of money market fund risks and financial crises. Finance and Economics Discussion Series 2010-51, Board of Governors of the Federal Reserve System.

Miller, M., Orr, D., 1966. A model of the demand for money by firms. The Quarterly Journal of Economics 80 (3), 413-435.

Munyan, B., 2015. Regulatory arbitrage in repo markets. Office of Financial Research Working Paper 1522.

Musto, D.K., 1997. Portfolio disclosures and year-end price shifts. Journal of Finance 52, 1563-1588.

Musto, D.K., 1999. Investment decisions depend on portfolio disclosures. Journal of Finance 54, 935-950.

Nickel, S., 1981. Biases in dynamic models with fixed effects. Econometrica 49, 1417-1426.

Petersen, M., 2009. Estimating standard errors in finance panel data sets: comparing approaches. Review of Financial Studies 22, 435-480.

Rzeznik, A., 2015. Mutual fund flight-to-liquidity. Working paper.

Schmidt, L., Timmerman, A., Wermers, R., 2016. Runs on money market mutual funds. American Economic Review 106, 2625-2657.

Vayanos, D., 2004. Flight to quality, flight to liquidity, and the pricing of risk. NBER Working paper.

Wermers, R., 2000. Mutual fund performance: an empirical decomposition into stock-picking talent, style, transactions costs, and expenses. Journal of Finance 55 (4), 1655-1695.

Witmer, J., 2012. Does the buck stop here? A comparison of withdrawals from money market funds with floating and constant share prices. Bank of Canada working paper.

Zeng, Y., 2016. A dynamic theory of mutual fund runs and liquidity management. Harvard University working paper. 
Table 1

Summary Statistics

This table reports summary statistics of fund-level averages of the variables over the entire sample for prime money market funds. Panel A includes all funds, Panel B includes only internal funds, and Panel C includes only external funds. Variable definitions are provided in Appendix A.

Panel A: All Funds

\begin{tabular}{|c|c|c|c|c|c|c|}
\hline VARIABLES & $\mathbf{N}$ & Mean & Median & $\sigma$ & Min & Max \\
\hline Weekly Liquidity & 238 & 0.518 & 0.474 & 0.141 & 0.334 & 0.999 \\
\hline Daily Liquidity & 238 & 0.315 & 0.288 & 0.136 & 0.113 & 0.855 \\
\hline Overnight Liquidity & 238 & 0.260 & 0.233 & 0.137 & 0 & 0.808 \\
\hline$\%$ Institutional & 238 & 0.398 & 0 & 0.467 & 0 & 1 \\
\hline Gross Yield & 238 & 20.84 & 22.34 & 7.423 & 0 & 35.50 \\
\hline Net Yield & 238 & 4.166 & 1.382 & 5.160 & 0 & 23.00 \\
\hline Fees & 238 & 16.81 & 18.14 & 8.348 & 0 & 34.45 \\
\hline Turnover & 238 & 0.261 & 0.158 & 0.275 & 0 & 1.558 \\
\hline Ln (AUM) & 238 & 21.07 & 20.98 & 2.005 & 16.12 & 25.53 \\
\hline Average Life Maturity & 238 & 59.45 & 58.25 & 21.96 & 2.509 & 105.9 \\
\hline Average Portfolio Maturity & 238 & 38.29 & 40.45 & 10.22 & 2.509 & 56.30 \\
\hline Net Flows & 238 & -0.0100 & -0.00420 & 0.0334 & -0.242 & 0.0435 \\
\hline External & 238 & 0.916 & 1 & 0.278 & 0 & 1 \\
\hline Own mutual fund holding \% & 238 & 0.0209 & 0 & 0.0858 & 0 & 0.712 \\
\hline \multicolumn{7}{|l|}{ Panel B: Internal Funds } \\
\hline VARIABLES & $\mathbf{N}$ & Mean & Median & $\sigma$ & Min & Max \\
\hline Weekly Liquidity & 7 & 0.569 & 0.488 & 0.182 & 0.368 & 0.852 \\
\hline Daily Liquidity & 7 & 0.281 & 0.235 & 0.169 & 0.172 & 0.642 \\
\hline Overnight Liquidity & 7 & 0.156 & 0.141 & 0.0644 & 0.0712 & 0.240 \\
\hline$\%$ Institutional & 7 & 0.727 & 1 & 0.467 & 0 & 1 \\
\hline Gross Yield & 7 & 20.11 & 22.06 & 6.193 & 9.796 & 26.85 \\
\hline Net Yield & 7 & 10.01 & 9.407 & 5.462 & 1.439 & 17.44 \\
\hline Fees & 7 & 10.16 & 11.10 & 9.466 & 0.700 & 23.05 \\
\hline Turnover & 7 & 0.614 & 0.650 & 0.301 & 0.237 & 1.043 \\
\hline $\operatorname{Ln}(A U M)$ & 7 & 22.64 & 22.74 & 1.608 & 20.04 & 24.26 \\
\hline Average Life Maturity & 7 & 64.13 & 69.65 & 17.53 & 36.89 & 88.81 \\
\hline Average Portfolio Maturity & 7 & 41.14 & 41.65 & 6.491 & 31.87 & 49.43 \\
\hline Net Flows & 7 & 0.0134 & 0.0161 & 0.00818 & 0.00298 & 0.0226 \\
\hline External & 7 & 0 & 0 & 0 & 0 & 0 \\
\hline Own mutual fund holding $\%$ & 7 & 0.445 & 0.337 & 0.212 & 0.234 & 0.712 \\
\hline
\end{tabular}


Table 1 (cont'd)

Panel C: External Funds

\begin{tabular}{|c|c|c|c|c|c|c|}
\hline VARIABLES & $\mathbf{N}$ & Mean & Median & $\sigma$ & Min & Max \\
\hline Weekly Liquidity & 231 & 0.516 & 0.474 & 0.139 & 0.334 & 0.999 \\
\hline Daily Liquidity & 231 & 0.316 & 0.290 & 0.135 & 0.113 & 0.855 \\
\hline Overnight Liquidity & 231 & 0.263 & 0.235 & 0.137 & 0 & 0.808 \\
\hline$\%$ Institutional & 231 & 0.388 & 0 & 0.465 & 0 & 1 \\
\hline Gross Yield & 231 & 20.87 & 22.38 & 7.468 & 0 & 35.50 \\
\hline Net Yield & 231 & 3.989 & 1.303 & 5.058 & 0 & 23.00 \\
\hline Fees & 231 & 17.01 & 18.17 & 8.252 & 0 & 34.45 \\
\hline Turnover & 231 & 0.250 & 0.151 & 0.268 & 0 & 1.558 \\
\hline Ln (AUM) & 231 & 21.02 & 20.95 & 1.999 & 16.12 & 25.53 \\
\hline Average Life Maturity & 231 & 59.31 & 58.22 & 22.09 & 2.509 & 105.9 \\
\hline Average Portfolio Maturity & 231 & 38.20 & 40.43 & 10.31 & 2.509 & 56.30 \\
\hline Net Flows & 231 & -0.0107 & -0.00440 & 0.0336 & -0.242 & 0.0435 \\
\hline External & 231 & 1 & 1 & 0 & 1 & 1 \\
\hline Own mutual fund holding \% & 231 & 0.00804 & 0 & 0.0278 & 0 & 0.174 \\
\hline
\end{tabular}


Table 2

Correlation tables

This table reports pairwise correlations of fund-level averages of the variables over the entire sample for prime money market funds. Correlations are reported only if they are statistically significant at the $10 \%$ threshold. Variable definitions are provided in Appendix A.

\begin{tabular}{|c|c|c|c|c|c|c|c|c|c|c|c|c|c|}
\hline & $\begin{array}{l}\text { Weekly } \\
\text { Liquidity }\end{array}$ & $\begin{array}{l}\text { Daily } \\
\text { Liquidity }\end{array}$ & $\begin{array}{l}\text { Overnight } \\
\text { Liquidity }\end{array}$ & \% Inst'l & $\begin{array}{l}\text { Gross } \\
\text { Yield }\end{array}$ & Net Yield & Fees & Turnover & $\begin{array}{l}\text { Ln } \\
\text { (AUM) }\end{array}$ & $\begin{array}{l}\text { Average } \\
\text { Life } \\
\text { Maturity }\end{array}$ & $\begin{array}{l}\text { Average } \\
\text { Portfolio } \\
\text { Maturity }\end{array}$ & Net Flows & External \\
\hline Daily Liquidity & 0.72 & & & & & & & & & & & & \\
\hline Overnight Liquidity & 0.64 & 0.93 & & & & & & & & & & & \\
\hline \multicolumn{14}{|l|}{$\%$ Institutional } \\
\hline Gross Yield & -0.16 & -0.18 & & 0.22 & & & & & & & & & \\
\hline Net Yield & & 0.13 & & 0.26 & 0.22 & & & & & & & & \\
\hline Fees & -0.17 & -0.22 & & & 0.77 & -0.45 & & & & & & & \\
\hline Turnover & & & 0.12 & 0.43 & & 0.37 & -0.16 & & & & & & \\
\hline Ln (AUM) & -0.32 & -0.12 & & 0.25 & 0.11 & 0.33 & -0.12 & 0.46 & & & & & \\
\hline $\begin{array}{l}\text { Average Life } \\
\text { Maturity }\end{array}$ & -0.58 & -0.47 & -0.45 & & 0.13 & & 0.12 & & 0.32 & & & & \\
\hline $\begin{array}{l}\text { Average Portfolio } \\
\text { Maturity }\end{array}$ & -0.72 & -0.61 & -0.64 & -0.12 & & -0.13 & 0.10 & -0.19 & 0.20 & 0.88 & & & \\
\hline Net Flows & -0.22 & -0.22 & -0.22 & & 0.11 & 0.22 & & 0.13 & 0.26 & 0.26 & 0.27 & & \\
\hline $\begin{array}{l}\text { Own mutual fund } \\
\text { holding } \%\end{array}$ & & & -0.11 & 0.15 & -0.10 & 0.14 & -0.18 & 0.21 & & & & 0.11 & -0.71 \\
\hline
\end{tabular}




\section{Table 3}

\section{Panel regressions describing fund liquidity}

The dependent variables in these panel regressions are different measures of fund liquidity. The first two columns use Weekly Liquidity as a dependent variable, the second two columns use Daily Liquidity as a dependent variable, and the two rightmost columns use Overnight Liquidity as a dependent variable. All variables are described in Appendix A. Standard errors are clustered by time period and by fund. Absolute values of $\mathrm{t}$ statistics are in parentheses. * indicates statistical significance at the $10 \%$ threshold, $* *$ indicates statistical significance at the $5 \%$ threshold and *** indicates statistical significance at the $1 \%$ threshold.

\begin{tabular}{|c|c|c|c|c|c|c|}
\hline & $\begin{array}{l}\text { Weekly } \\
\text { Liquidity }\end{array}$ & $\begin{array}{l}\text { Weekly } \\
\text { Liquidity }\end{array}$ & $\begin{array}{c}\text { Daily } \\
\text { Liquidity }\end{array}$ & $\begin{array}{c}\text { Daily } \\
\text { Liquidity }\end{array}$ & $\begin{array}{l}\text { Overnight } \\
\text { Liquidity }\end{array}$ & $\begin{array}{l}\text { Overnight } \\
\text { Liquidity }\end{array}$ \\
\hline External & $\begin{array}{c}-0.071 \\
(1.20)\end{array}$ & $\begin{array}{c}-0.069 \\
(1.17)\end{array}$ & $\begin{array}{l}0.025 \\
(0.39)\end{array}$ & $\begin{array}{l}0.029 \\
(0.45)\end{array}$ & $\begin{array}{c}0.112 \\
(3.56)^{* * *}\end{array}$ & $\begin{array}{c}0.116 \\
(3.95)^{* * *}\end{array}$ \\
\hline Maturity t-1 & $\begin{array}{l}0.000 \\
(0.02)\end{array}$ & $\begin{array}{l}0.000 \\
(0.01)\end{array}$ & $\begin{array}{c}0.002 \\
(4.29)^{* * *}\end{array}$ & $\begin{array}{c}0.002 \\
(4.59)^{* * *}\end{array}$ & $\begin{array}{c}0.002 \\
(3.89)^{* * *}\end{array}$ & $\begin{array}{c}0.002 \\
(4.25)^{* * *}\end{array}$ \\
\hline $\operatorname{Ln}(A U M)_{t-1}$ & $\begin{array}{c}-0.025 \\
(4.66)^{* * *}\end{array}$ & $\begin{array}{c}-0.023 \\
(3.71)^{* * *}\end{array}$ & $\begin{array}{c}-0.018 \\
(3.93)^{* * *}\end{array}$ & $\begin{array}{l}-0.015 \\
(2.37)^{* *}\end{array}$ & $\begin{array}{c}-0.017 \\
(3.48)^{* * *}\end{array}$ & $\begin{array}{l}-0.013 \\
(1.93)^{*}\end{array}$ \\
\hline$\%$ Institutional $_{\mathrm{t}-1}$ & $\begin{array}{c}0.108 \\
(4.95)^{* * *}\end{array}$ & $\begin{array}{c}0.101 \\
(3.94)^{* * *}\end{array}$ & $\begin{array}{c}0.096 \\
(4.50)^{* * *}\end{array}$ & $\begin{array}{c}0.083 \\
(3.16)^{* * *}\end{array}$ & $\begin{array}{c}0.081 \\
(3.86)^{* * *}\end{array}$ & $\begin{array}{c}0.067 \\
(2.43)^{* *}\end{array}$ \\
\hline Turnover ${ }_{t-1}$ & $\begin{array}{c}0.007 \\
(0.28)\end{array}$ & $\begin{array}{c}-0.004 \\
(0.15)\end{array}$ & $\begin{array}{c}0.032 \\
(1.27)\end{array}$ & $\begin{array}{c}0.012 \\
(0.56)\end{array}$ & $\begin{array}{c}0.065 \\
(2.78)^{* * *}\end{array}$ & $\begin{array}{c}0.042 \\
(2.18)^{* *}\end{array}$ \\
\hline Ted Spread ${ }_{t-1}$ & $\begin{array}{c}0.198 \\
(6.43)^{* * *}\end{array}$ & & $\begin{array}{c}0.147 \\
(5.12)^{* * *}\end{array}$ & & $\begin{array}{c}0.102 \\
(4.42)^{* * *}\end{array}$ & \\
\hline Net Flows ${ }_{t-1}$ & $\begin{array}{l}0.025 \\
(1.03)\end{array}$ & $\begin{array}{l}0.021 \\
(0.93)\end{array}$ & $\begin{array}{c}0.059 \\
(2.17)^{* *}\end{array}$ & $\begin{array}{c}0.054 \\
(2.13)^{* *}\end{array}$ & $\begin{array}{c}0.066 \\
(2.62)^{* *}\end{array}$ & $\begin{array}{c}0.063 \\
(2.60)^{* *}\end{array}$ \\
\hline$\sigma^{\text {Flows }}$ & & $\begin{array}{l}0.268 \\
(1.02)\end{array}$ & & $\begin{array}{c}0.458 \\
(1.68)^{*}\end{array}$ & & $\begin{array}{c}0.496 \\
(1.68)^{*}\end{array}$ \\
\hline 1 Year Spread $_{\mathrm{t}-1}$ & $\begin{array}{r}-0.055 \\
(1.18)\end{array}$ & & $\begin{array}{c}-0.110 \\
(2.75)^{* * *}\end{array}$ & & $\begin{array}{c}-0.034 \\
(1.05)\end{array}$ & \\
\hline Leverage $_{t-1}$ & $\begin{array}{c}0.256 \\
(2.01)^{*}\end{array}$ & $\begin{array}{c}0.231 \\
(1.71)^{*}\end{array}$ & $\begin{array}{c}0.311 \\
(2.73)^{* * *}\end{array}$ & $\begin{array}{c}0.273 \\
(2.21)^{* *}\end{array}$ & $\begin{array}{c}0.283 \\
(3.82)^{* * *}\end{array}$ & $\begin{array}{c}0.245 \\
(2.95)^{* * * *}\end{array}$ \\
\hline$R^{2}$ & 0.20 & 0.21 & 0.20 & 0.22 & 0.21 & 0.23 \\
\hline$N$ & 10,001 & 10,001 & 10,001 & 10,001 & 10,001 & 10,001 \\
\hline Fixed Time Effects & NO & YES & NO & YES & $\mathrm{NO}$ & YES \\
\hline
\end{tabular}




\section{Table 4}

\section{Fixed effect panel regressions describing fund liquidity at quarter end}

The dependent variables in these fixed effect panel regressions are different measures of fund liquidity. The first two columns use Weekly Liquidity as a

dependent variable, the second two columns use Daily Liquidity as a dependent variable, and the two rightmost columns use Overnight Liquidity as a dependent variable. All variables are described in Appendix A. Standard errors are clustered by time period and by fund. Absolute values of $t$ statistics are in parentheses. indicates statistical significance at the $10 \%$ threshold, $* *$ indicates statistical significance at the $5 \%$ threshold and $* * *$ indicates statistical significance at the $1 \%$ threshold.

\begin{tabular}{|c|c|c|c|c|c|c|}
\hline & $\begin{array}{l}\text { Weekly } \\
\text { Liquidity }\end{array}$ & $\begin{array}{l}\text { Weekly } \\
\text { Liquidity }\end{array}$ & $\begin{array}{c}\text { Daily } \\
\text { Liquidity }\end{array}$ & $\begin{array}{c}\text { Daily } \\
\text { Liquidity }\end{array}$ & $\begin{array}{l}\text { Overnight } \\
\text { Liquidity }\end{array}$ & $\begin{array}{l}\text { Overnight } \\
\text { Liquidity }\end{array}$ \\
\hline Maturity $t-1$ & $\begin{array}{r}-0.001 \\
(1.38)\end{array}$ & $\begin{array}{c}-0.001 \\
(1.33)\end{array}$ & $\begin{array}{c}0.001 \\
(2.26)^{* *}\end{array}$ & $\begin{array}{c}0.001 \\
(2.09)^{* *}\end{array}$ & $\begin{array}{r}0.000 \\
(1.79)^{*}\end{array}$ & $\begin{array}{c}0.000 \\
(2.07)^{* *}\end{array}$ \\
\hline $\operatorname{Ln}(A U M)_{t-1}$ & $\begin{array}{c}-0.011 \\
(1.45)\end{array}$ & $\begin{array}{r}-0.010 \\
(1.38)\end{array}$ & $\begin{array}{c}-0.000 \\
(0.01)\end{array}$ & $\begin{array}{l}0.001 \\
(0.16)\end{array}$ & $\begin{array}{c}-0.008 \\
(0.80)\end{array}$ & $\begin{array}{c}-0.009 \\
(0.90)\end{array}$ \\
\hline$\%$ Institutional $_{\mathrm{t}-1}$ & $\begin{array}{l}0.030 \\
(0.72)\end{array}$ & $\begin{array}{l}0.027 \\
(0.61)\end{array}$ & $\begin{array}{r}-0.037 \\
(0.37)\end{array}$ & $\begin{array}{c}-0.045 \\
(0.45)\end{array}$ & $\begin{array}{c}-0.034 \\
(0.32)\end{array}$ & $\begin{array}{c}-0.036 \\
(0.33)\end{array}$ \\
\hline Turnover ${ }_{\mathrm{t}-1}$ & $\begin{array}{r}-0.009 \\
(0.89)\end{array}$ & $\begin{array}{r}-0.007 \\
(0.65)\end{array}$ & $\begin{array}{l}0.007 \\
(0.57)\end{array}$ & $\begin{array}{l}0.009 \\
(0.75)\end{array}$ & $\begin{array}{c}0.025 \\
(2.10)^{* *}\end{array}$ & $\begin{array}{c}0.025 \\
(2.05)^{* *}\end{array}$ \\
\hline Ted Spread ${ }_{t-1}$ & $\begin{array}{c}0.121 \\
(4.94)^{* * *}\end{array}$ & & $\begin{array}{c}0.077 \\
(3.04)^{* * *}\end{array}$ & & $\begin{array}{c}0.073 \\
(3.80)^{* * *}\end{array}$ & \\
\hline Net Flows ${ }_{t-1}$ & $\begin{array}{c}0.037 \\
(2.00)^{*}\end{array}$ & $\begin{array}{r}0.035 \\
(1.88)^{*}\end{array}$ & $\begin{array}{c}0.099 \\
(5.17)^{* * *}\end{array}$ & $\begin{array}{c}0.097 \\
(4.97)^{* * *}\end{array}$ & $\begin{array}{c}0.100 \\
(4.90)^{* * *}\end{array}$ & $\begin{array}{c}0.098 \\
(4.70)^{* * *}\end{array}$ \\
\hline 1 Year Spread ${ }_{t-1}$ & $\begin{array}{c}-0.084 \\
(2.36)^{* *}\end{array}$ & & $\begin{array}{c}-0.116 \\
(2.96)^{* * *}\end{array}$ & & $\begin{array}{r}-0.029 \\
(0.89)\end{array}$ & \\
\hline Leverage $_{t-1}$ & $\begin{array}{l}0.050 \\
(0.94)\end{array}$ & $\begin{array}{l}0.056 \\
(1.03)\end{array}$ & $\begin{array}{c}0.124 \\
(1.72)^{*}\end{array}$ & $\begin{array}{c}0.133 \\
(1.78)^{*}\end{array}$ & $\begin{array}{c}0.081 \\
(2.13)^{* *}\end{array}$ & $\begin{array}{c}0.083 \\
(2.13)^{* *}\end{array}$ \\
\hline ORRP & $\begin{array}{c}-0.021 \\
(3.49)^{* * *}\end{array}$ & & $\begin{array}{c}-0.018 \\
(3.07)^{* * *}\end{array}$ & & $\begin{array}{r}-0.003 \\
(0.58)\end{array}$ & \\
\hline Quarter & $\begin{array}{r}-0.001 \\
(0.13)\end{array}$ & & $\begin{array}{r}-0.005 \\
(0.50)\end{array}$ & & $\begin{array}{c}-0.020 \\
(4.56)^{* * *}\end{array}$ & \\
\hline External $*$ Quarter & $\begin{array}{l}0.005 \\
(0.95)\end{array}$ & $\begin{array}{l}0.005 \\
(0.91)\end{array}$ & $\begin{array}{l}0.001 \\
(0.16)\end{array}$ & $\begin{array}{l}0.001 \\
(0.15)\end{array}$ & $\begin{array}{c}0.009 \\
(2.14)^{* *}\end{array}$ & $\begin{array}{c}0.009 \\
(2.20)^{* *}\end{array}$ \\
\hline ORRP * Quarter & $\begin{array}{c}0.019 \\
(1.41)\end{array}$ & & $\begin{array}{l}0.006 \\
(0.40)\end{array}$ & & $\begin{array}{c}0.017 \\
(2.03)^{* *}\end{array}$ & \\
\hline External * ORRP * Quarter & $\begin{array}{c}-0.018 \\
(1.44)\end{array}$ & $\begin{array}{c}-0.018 \\
(1.41)\end{array}$ & $\begin{array}{l}0.005 \\
(0.47)\end{array}$ & $\begin{array}{l}0.006 \\
(0.47)\end{array}$ & $\begin{array}{c}-0.005 \\
(0.72)\end{array}$ & $\begin{array}{c}-0.006 \\
(0.78)\end{array}$ \\
\hline$R^{2}$ & 0.76 & 0.77 & 0.72 & 0.73 & 0.75 & 0.75 \\
\hline$N$ & 9,998 & 9,998 & 9,998 & 9,998 & 9,998 & 9,998 \\
\hline Fixed Time Effects & $\mathrm{NO}$ & YES & NO & YES & NO & YES \\
\hline Fixed Fund Effects & YES & YES & YES & YES & YES & YES \\
\hline
\end{tabular}


Table 5

OLS regressions investigating the minimum and maximum of fund's liquidity measures

The dependent variable is equal to the in-sample minimum or maximum of a fund's liquidity over the sample period from January 2011 through April 2015 . The independent variables are either fund-level means or standard deviations of explanatory variables used in the previous tables. Absolute values of $t$ statistics are in parentheses (using robust standard errors). * indicates statistical significance at the $10 \%$ threshold, $* *$ indicates statistical significance at the $5 \%$ threshold and $* * *$ indicates statistical significance at the $1 \%$ threshold.

\begin{tabular}{|c|c|c|c|c|c|c|}
\hline & \multicolumn{2}{|c|}{ Weekly Liquidity } & \multicolumn{2}{|c|}{ Daily Liquidity } & \multicolumn{2}{|c|}{ Overnight Liquidity } \\
\hline $\operatorname{Ln}(\mathrm{AUM})$ & $\begin{array}{c}\text { Minimum } \\
-0.020 \\
(3.12)^{* * *}\end{array}$ & $\begin{array}{c}\text { Maximum } \\
-0.035 \\
(5.36)^{* * *}\end{array}$ & $\begin{array}{c}\text { Minimum } \\
-0.007 \\
(1.36)\end{array}$ & $\begin{array}{c}\text { Maximum } \\
-0.030 \\
(3.78)^{* * *}\end{array}$ & $\begin{array}{r}\text { Minimum } \\
-0.006 \\
(1.21)\end{array}$ & $\begin{array}{r}\text { Maximum } \\
-0.022 \\
(2.56)^{* *}\end{array}$ \\
\hline Maturity & $\begin{array}{l}-0.001 \\
(0.66)\end{array}$ & $\begin{array}{c}0.000 \\
(0.16)\end{array}$ & $\begin{array}{l}0.002 \\
(5.35)^{* * *}\end{array}$ & $\begin{array}{l}0.003 \\
(3.87)^{* * *}\end{array}$ & $\begin{array}{r}0.002 \\
(5.80)^{* * *}\end{array}$ & $\begin{array}{r}0.003 \\
(4.52)^{* * *}\end{array}$ \\
\hline$\sigma^{\text {Gross Yield }}$ & $\begin{array}{c}0.003 \\
(0.57)\end{array}$ & $\begin{array}{c}0.018 \\
(2.85)^{* * *}\end{array}$ & $\begin{array}{c}0.007 \\
(1.47)\end{array}$ & $\begin{array}{l}0.019 \\
(2.54)^{* *}\end{array}$ & $\begin{array}{l}0.008 \\
(1.63)\end{array}$ & $\begin{array}{r}0.018 \\
(2.51)^{* *}\end{array}$ \\
\hline Gross Yield & $\begin{array}{l}-0.001 \\
(0.43)\end{array}$ & $\begin{array}{l}-0.006 \\
(3.43)^{* * *}\end{array}$ & $\begin{array}{l}-0.003 \\
(2.25)^{* *}\end{array}$ & $\begin{array}{l}-0.008 \\
(3.67)^{* * *}\end{array}$ & $\begin{array}{c}-0.001 \\
(0.54)\end{array}$ & $\begin{array}{l}-0.004 \\
(1.76)^{*}\end{array}$ \\
\hline$\sigma^{\text {Flows }}$ & $\begin{array}{c}0.211 \\
(0.65)\end{array}$ & $\begin{array}{c}0.761 \\
(2.81)^{* * *}\end{array}$ & $\begin{array}{l}-0.067 \\
(0.26)\end{array}$ & $\begin{array}{c}0.825 \\
(2.06)^{* *}\end{array}$ & $\begin{array}{l}0.068 \\
(0.27)\end{array}$ & $\begin{array}{r}1.032 \\
(2.36)^{* *}\end{array}$ \\
\hline Turnover & $\begin{array}{l}-0.033 \\
(1.15)\end{array}$ & $\begin{array}{c}0.040 \\
(0.99)\end{array}$ & $\begin{array}{c}0.011 \\
(0.42)\end{array}$ & $\begin{array}{c}0.030 \\
(0.60)\end{array}$ & $\begin{array}{c}0.018 \\
(0.71)\end{array}$ & $\begin{array}{r}0.078 \\
(1.71)^{*}\end{array}$ \\
\hline External & $\begin{array}{l}-0.058 \\
(1.39)\end{array}$ & $\begin{array}{l}-0.009 \\
(0.16)\end{array}$ & $\begin{array}{l}0.057 \\
(3.04)^{* * *}\end{array}$ & $\begin{array}{l}0.050 \\
(0.63)\end{array}$ & $\begin{array}{r}0.070 \\
(3.86)^{* * *}\end{array}$ & $\begin{array}{r}0.163 \\
(5.45)^{* * *}\end{array}$ \\
\hline$\%$ Institutional & $\begin{array}{c}0.073 \\
(2.83)^{* * *}\end{array}$ & $\begin{array}{c}0.065 \\
(2.94)^{* * *}\end{array}$ & $\begin{array}{c}0.048 \\
(2.23)^{* *}\end{array}$ & $\begin{array}{c}0.080 \\
(2.56)^{* *}\end{array}$ & $\begin{array}{r}0.044 \\
(2.12)^{* *}\end{array}$ & $\begin{array}{c}0.054 \\
(1.56)\end{array}$ \\
\hline Constant & $\begin{array}{c}0.860 \\
(5.46)^{* * *}\end{array}$ & $\begin{array}{c}1.370 \\
(9.32)^{* * *}\end{array}$ & $\begin{array}{c}0.159 \\
(1.31)\end{array}$ & $\begin{array}{c}0.861 \\
(4.37)^{* * *}\end{array}$ & $\begin{array}{l}0.023 \\
(0.19)\end{array}$ & $\begin{array}{r}0.430 \\
(1.92)^{*}\end{array}$ \\
\hline$R^{2}$ & 0.19 & 0.36 & 0.17 & 0.29 & 0.17 & 0.26 \\
\hline$N$ & 237 & 237 & 237 & 237 & 237 & 237 \\
\hline
\end{tabular}




\section{Table 6}

Dynamic panel fixed effect regressions of speed of adjustment equation

The speed of adjustment in these regressions is equal to 1 minus the coefficient on the lagged dependent variable. Standard errors are clustered by time period and by fund. Absolute values of $t$ statistics are in parentheses. * indicates statistical significance at the $10 \%$ threshold, $* *$ indicates statistical significance at the $5 \%$ threshold and $* * *$ indicates statistical significance at the $1 \%$ threshold.

\begin{tabular}{|c|c|c|c|}
\hline & $\begin{array}{l}\text { Weekly } \\
\text { Liquidity t }\end{array}$ & $\begin{array}{c}\text { Daily } \\
\text { Liquidity } t\end{array}$ & $\begin{array}{l}\text { Overnight } \\
\text { Liquidity } t\end{array}$ \\
\hline Maturity $t-1$ & $\begin{array}{c}-0.000 \\
(1.38)\end{array}$ & $\begin{array}{l}-0.000 \\
(1.27)\end{array}$ & $\begin{array}{l}-0.000 \\
(1.14)\end{array}$ \\
\hline Turnover $_{t-1}$ & $\begin{array}{l}-0.004 \\
(0.78)\end{array}$ & $\begin{array}{r}0.009 \\
(1.40)\end{array}$ & $\begin{array}{c}0.018 \\
(2.46)^{* *}\end{array}$ \\
\hline $\operatorname{Ln}(A U M)_{t-1}$ & $\begin{array}{l}-0.004 \\
(1.13)\end{array}$ & $\begin{array}{r}0.004 \\
(0.82)\end{array}$ & $\begin{array}{r}-0.001 \\
(0.20)\end{array}$ \\
\hline$\%$ Institutional $_{\mathrm{t}-1}$ & $\begin{array}{r}0.006 \\
(0.34)\end{array}$ & $\begin{array}{l}-0.055 \\
(0.97)\end{array}$ & $\begin{array}{l}-0.056 \\
(0.81)\end{array}$ \\
\hline Leverage $_{t-1}$ & $\begin{array}{c}-0.016 \\
(0.40)\end{array}$ & $\begin{array}{r}0.027 \\
(0.66)\end{array}$ & $\begin{array}{r}0.023 \\
(0.70)\end{array}$ \\
\hline Net Flows $_{t}$ & $\begin{array}{c}0.087 \\
(5.18)^{* * * *}\end{array}$ & $\begin{array}{c}0.130 \\
(7.15)^{* * *}\end{array}$ & $\begin{array}{c}0.133 \\
(6.81)^{* * *}\end{array}$ \\
\hline Weekly Liquidity $\mathrm{t}-1$ & $\begin{array}{c}0.678 \\
(8.59)^{* * *}\end{array}$ & & \\
\hline External * Weekly Liquidity ${ }_{\mathrm{t}-1}$ & $\begin{array}{r}-0.091 \\
(1.08)\end{array}$ & & \\
\hline Daily Liquidity $t-1$ & & $\begin{array}{c}0.730 \\
(9.32)^{* * *}\end{array}$ & \\
\hline External * Daily Liquidity $\mathrm{t}-1$ & & $\begin{array}{c}-0.174 \\
(2.06)^{* *}\end{array}$ & \\
\hline Overnight Liquidity $\mathrm{t}-1$ & & & $\begin{array}{c}0.234 \\
(3.33)^{* * *}\end{array}$ \\
\hline External * Overnight Liquidity ${ }_{t-1}$ & & & $\begin{array}{c}0.233 \\
(3.07)^{* * *}\end{array}$ \\
\hline$R^{2}$ & 0.85 & 0.81 & 0.80 \\
\hline$N$ & 9,995 & 9,995 & 9,995 \\
\hline
\end{tabular}


Table 7

Determinants of prime fund overnight liquidity using alternative definitions of External

The first column reproduces the results from Table 3. The second and third columns define external funds as those with less than $10 \%$ or less than $5 \%$ of their shareholder base coming from the same fund family in December 2010 . The final columns use the proportion of the shareholder base that is from the same family (and outside the family) as of December 2010 as a direct measure of strategic complementarities. Standard errors are clustered by time period and by fund. Absolute values of z statistics are in parentheses. * indicates statistical significance at the $10 \%$

threshold, $* *$ indicates statistical significance at the $5 \%$ threshold and $* * *$ indicates statistical significance at the $1 \%$ threshold.

\begin{tabular}{|c|c|c|c|c|c|}
\hline & (1) & (2) & (3) & (4) & $(5)$ \\
\hline External & $\begin{array}{c}0.116 \\
(3.95)^{* * *}\end{array}$ & & & & \\
\hline External ( $10 \%$ threshold) & & $\begin{array}{c}0.064 \\
(2.56)^{* *}\end{array}$ & & & \\
\hline External (5\% threshold) & & & $\begin{array}{c}0.058 \\
(2.79)^{* * *}\end{array}$ & & \\
\hline Own mutual fund holding $\%$ & & & & $\begin{array}{c}-0.192 \\
(2.50)^{* *}\end{array}$ & $\begin{array}{l}-0.173 \\
(1.92)^{*}\end{array}$ \\
\hline Other mutual fund holding $\%$ & & & & & $\begin{array}{c}0.646 \\
(0.77)\end{array}$ \\
\hline Maturity $\mathrm{t}-1$ & $\begin{array}{c}0.002 \\
(4.25)^{* * *}\end{array}$ & $\begin{array}{c}0.002 \\
(4.35)^{* * *}\end{array}$ & $\begin{array}{c}0.002 \\
(4.48)^{* * *}\end{array}$ & $\begin{array}{r}0.002 \\
(4.08)^{* * * *}\end{array}$ & $\begin{array}{r}0.002 \\
(4.08)^{* * * *}\end{array}$ \\
\hline $\operatorname{Ln}(A U M)_{t-1}$ & $\begin{array}{c}-0.013 \\
(1.93)^{*}\end{array}$ & $\begin{array}{l}-0.014 \\
(2.05)^{* *}\end{array}$ & $\begin{array}{l}-0.014 \\
(2.12)^{* *}\end{array}$ & $\begin{array}{r}-0.017 \\
(3.43)^{* * *}\end{array}$ & $\begin{array}{r}-0.017 \\
(3.40)^{* * *}\end{array}$ \\
\hline$\%$ Institutional $\mathrm{t}-1$ & $\begin{array}{c}0.067 \\
(2.43)^{* *}\end{array}$ & $\begin{array}{c}0.070 \\
(2.55)^{* *}\end{array}$ & $\begin{array}{c}0.069 \\
(2.54)^{* *}\end{array}$ & $\begin{array}{r}0.082 \\
(3.87)^{* * *}\end{array}$ & $\begin{array}{r}0.082 \\
(3.90)^{* * *}\end{array}$ \\
\hline Turnover $_{t-1}$ & $\begin{array}{c}0.042 \\
(2.18)^{* *}\end{array}$ & $\begin{array}{c}0.044 \\
(2.08)^{* *}\end{array}$ & $\begin{array}{c}0.049 \\
(2.37)^{* *}\end{array}$ & $\begin{array}{r}0.064 \\
(2.68)^{* * *}\end{array}$ & $\begin{array}{r}0.065 \\
(2.70)^{* * *}\end{array}$ \\
\hline Net Flows $_{t-1}$ & $\begin{array}{c}0.063 \\
(2.60)^{* *}\end{array}$ & $\begin{array}{c}0.060 \\
(2.47)^{* *}\end{array}$ & $\begin{array}{c}0.058 \\
(2.35)^{* *}\end{array}$ & $\begin{array}{r}0.063 \\
(2.54)^{* *}\end{array}$ & $\begin{array}{r}0.062 \\
(2.52)^{* *}\end{array}$ \\
\hline Leverage $_{t-1}$ & $\begin{array}{c}0.245 \\
(2.95)^{* * *}\end{array}$ & $\begin{array}{c}0.258 \\
(3.07)^{* * *}\end{array}$ & $\begin{array}{c}0.253 \\
(3.00)^{* * *}\end{array}$ & $\begin{array}{r}0.287 \\
(3.79)^{* * *}\end{array}$ & $\begin{array}{r}0.286 \\
(3.79)^{* * *}\end{array}$ \\
\hline$\sigma^{\text {Flows }}$ & $\begin{array}{c}0.496 \\
(1.68)^{*}\end{array}$ & $\begin{array}{c}0.430 \\
(1.46)\end{array}$ & $\begin{array}{c}0.446 \\
(1.52)\end{array}$ & & \\
\hline$R^{2}$ & 0.23 & 0.22 & 0.22 & 0.21 & 0.21 \\
\hline$N$ & 10,001 & 10,001 & 10,001 & 10,001 & 10,001 \\
\hline Fixed Time Effects & YES & YES & YES & YES & YES \\
\hline
\end{tabular}


Table 8

Alternate estimation methods for determinants of prime fund overnight liquidity

This table illustrates how different estimation methods impact our main results on overnight liquidity from Table 3. The first column clusters by both time and fund and reproduces the result in Table $\mathbf{3}$. The second column clusters only by fund and not by time. In the third column, the same model is estimated using a random effects regression, while the fourth column estimates the results using Fama-MacBeth regressions. Absolute values of $\mathrm{z}$ statistics are in parentheses. * indicates statistical significance at the $10 \%$ threshold, ** indicates statistical significance at the $5 \%$ threshold and $* * *$ indicates statistical significance at the $1 \%$ threshold.

\begin{tabular}{|c|c|c|c|c|}
\hline & Pooled OLS & Pooled OLS & $\begin{array}{l}\text { Random } \\
\text { Effects }\end{array}$ & $\begin{array}{c}\text { Fama- } \\
\text { MacBeth }\end{array}$ \\
\hline External & $\begin{array}{c}0.112 \\
(3.56)^{* * *}\end{array}$ & $\begin{array}{r}0.112 \\
(3.56)^{* * *}\end{array}$ & $\begin{array}{r}0.111 \\
(4.07)^{* * *}\end{array}$ & $\begin{array}{r}0.110 \\
(27.60)^{* * *}\end{array}$ \\
\hline Maturity t-1 & $\begin{array}{c}0.002 \\
(3.89)^{* * *}\end{array}$ & $\begin{array}{r}0.002 \\
(3.91)^{* * *}\end{array}$ & $\begin{array}{r}0.000 \\
(2.06)^{* *}\end{array}$ & $\begin{array}{r}0.002 \\
(20.30)^{* * *}\end{array}$ \\
\hline $\operatorname{Ln}(A U M)_{t-1}$ & $\begin{array}{l}-0.017 \\
(3.48)^{* * *}\end{array}$ & $\begin{array}{r}-0.017 \\
(3.48)^{* * *}\end{array}$ & $\begin{array}{r}-0.012 \\
(1.54)\end{array}$ & $\begin{array}{r}-0.018 \\
(27.29)^{* * *}\end{array}$ \\
\hline$\%$ Institutional $_{\mathrm{t}-1}$ & $\begin{array}{c}0.081 \\
(3.86)^{* * *}\end{array}$ & $\begin{array}{r}0.081 \\
(3.85)^{* * *}\end{array}$ & $\begin{array}{l}0.040 \\
(1.06)\end{array}$ & $\begin{array}{r}0.081 \\
(34.60)^{* * *}\end{array}$ \\
\hline Turnover ${ }_{\mathrm{t}-1}$ & $\begin{array}{c}0.065 \\
(2.78)^{* * *}\end{array}$ & $\begin{array}{r}0.065 \\
(2.79)^{* * *}\end{array}$ & $\begin{array}{r}0.025 \\
(2.34)^{* *}\end{array}$ & $\begin{array}{r}0.067 \\
(15.34)^{* * *}\end{array}$ \\
\hline Ted Spread $_{t}$ & $\begin{array}{c}0.102 \\
(4.42)^{* * *}\end{array}$ & $\begin{array}{r}0.102 \\
(5.44)^{* * *}\end{array}$ & $\begin{array}{r}0.068 \\
(4.76)^{* * *}\end{array}$ & 0.000 \\
\hline Net Flows ${ }_{t-1}$ & $\begin{array}{l}0.066 \\
(2.62)^{* *}\end{array}$ & $\begin{array}{r}0.066 \\
(2.42)^{* *}\end{array}$ & $\begin{array}{r}0.095 \\
(4.69)^{* * *}\end{array}$ & $\begin{array}{r}0.058 \\
(3.09)^{* * *}\end{array}$ \\
\hline 1 Year Spread $_{\mathrm{t}}$ & $\begin{array}{l}-0.034 \\
(1.05)\end{array}$ & $\begin{array}{r}-0.034 \\
(1.37)\end{array}$ & $\begin{array}{r}-0.058 \\
(2.86)^{* * *}\end{array}$ & 0.000 \\
\hline Leverage $_{t-1}$ & $\begin{array}{c}0.283 \\
(3.82)^{* * *}\end{array}$ & $\begin{array}{r}0.283 \\
(3.88)^{* * *}\end{array}$ & $\begin{array}{r}0.087 \\
(2.48)^{* *}\end{array}$ & $\begin{array}{r}0.318 \\
(14.01)^{* * *}\end{array}$ \\
\hline$R^{2}$ & 0.21 & 0.21 & 0.15 & 0.25 \\
\hline$N$ & 10,001 & 10,001 & 9,999 & 10,001 \\
\hline Cluster by Time & YES & $\mathrm{NO}$ & NO & NA \\
\hline Cluster by Fund & YES & YES & YES & NA \\
\hline
\end{tabular}




\section{Table 9}

Propensity Score and Mahalanobis matching

The values in this table represent differences in Overnight Liquidity between internal money market funds (treatment group) and a control group of external funds. The first two columns use propensity score matching and the second two columns use Mahalanobis matching. The table reports both the Average Treatment Effect for the Treated (ATET) as well as the Average Treatment Effect (ATE). Money market funds are matched based on \% Institutional, Ln (AUM) and Turnover. Absolute values of $\mathrm{z}$ statistics are in parentheses. * indicates statistical significance at the $10 \%$ threshold, $* *$ indicates statistical significance at the $5 \%$ threshold and $* * *$ indicates statistical significance at the $1 \%$ threshold.

\begin{tabular}{lcccc}
\hline & $(1)$ & $(2)$ & $(3)$ & $(4)$ \\
\hline ATET & -0.147 & -0.138 & -0.138 & -0.179 \\
& $(3.81)^{* *}$ & $(6.98)^{* * *}$ & $(2.85)^{* * *}$ & $(4.12)^{* * *}$ \\
ATE & -0.141 & -0.107 & -0.176 & -0.151 \\
$N$ & $(2.50)^{* *}$ & $(3.51)^{* * *}$ & $(4.63)^{* * *}$ & $(5.09)^{* * *}$ \\
Matching Type & 243 & 243 & 243 & 243 \\
\# of Neighbors & Propensity Score & Propensity Score & Mahalanobis & Mahalanobis \\
Matching Variables & 1 & & & 3 \\
& \% Institutional & \% Institutional & \% Institutional & \% Institutional \\
& Ln (AUM) & Ln (AUM) & Ln (AUM) \\
& Turnover & Turnover & Turnover & Turnover \\
\hline
\end{tabular}


Figure 1. Distribution of average Overnight Liquidity at prime money market mutual funds

This histogram displays the distribution of average Overnight Liquidity. For each fund, this average is a simple average of its monthly Overnight Liquidity measure over the entire sample period. Overnight Liquidity is the proportion of the fund's portfolio invested in securities maturing on the next business day.

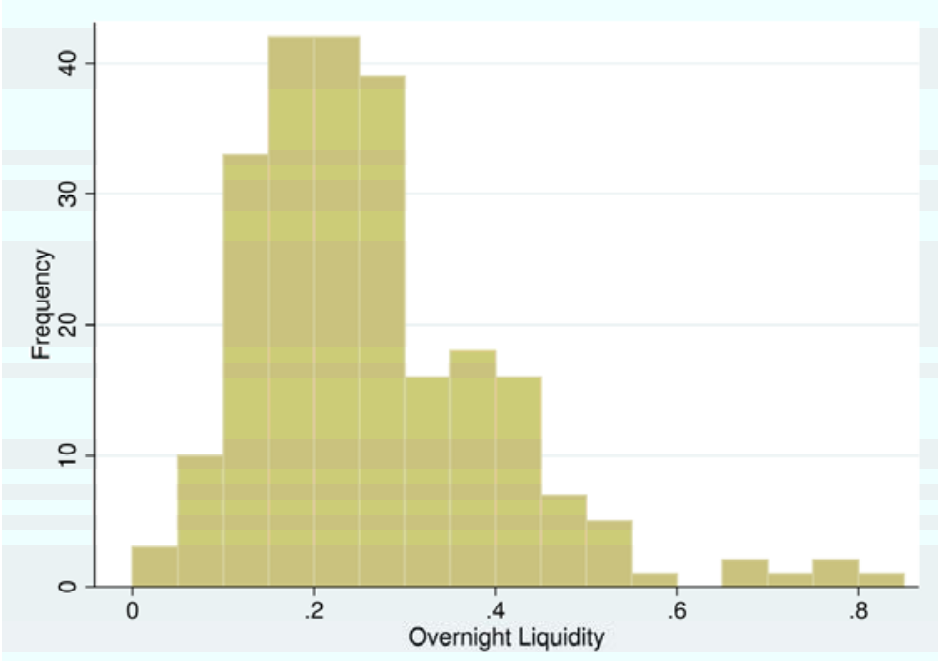


Figure 2. Distribution of average Daily Liquidity at prime money market mutual funds

This histogram displays the distribution of average Daily Liquidity. For each fund, this average is a simple average of its monthly Daily Liquidity measure over the entire sample period. Daily Liquidity is the proportion of the fund's portfolio invested in Treasury securities as well as securities maturing on the next business day. The regulatory minimum Daily Liquidity is $10 \%$.

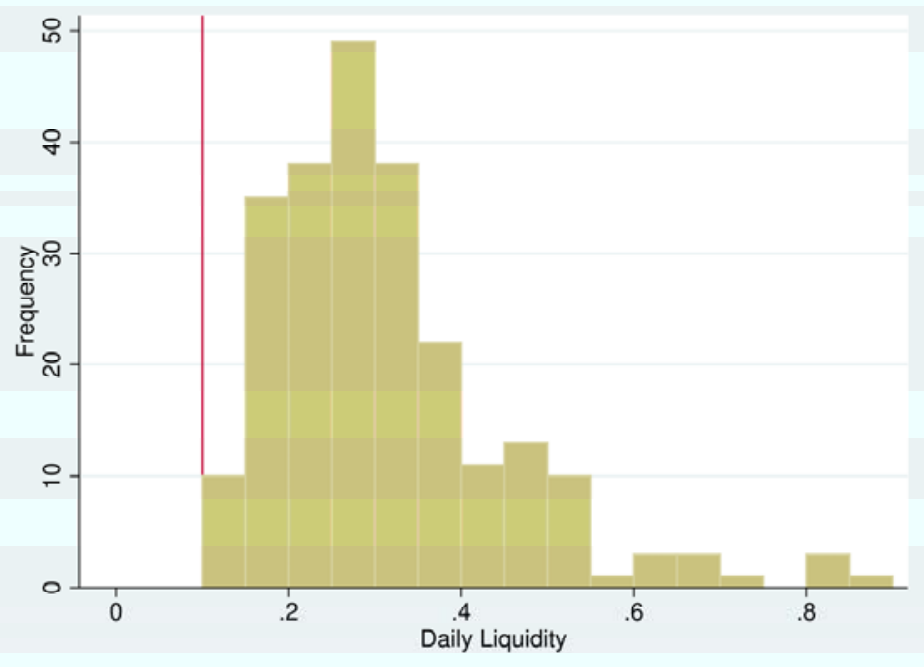


Figure 3. Distribution of average Weekly Liquidity at prime money market mutual funds

This histogram displays the distribution of average Weekly Liquidity. For each fund, this average is a simple average of its monthly Weekly Liquidity measure over the entire sample period. Weekly Liquidity is the proportion of the fund's portfolio invested in Treasury securities, securities maturing within the next business day, as well as certain government guaranteed securities with less than 60 days to maturity. The regulatory minimum Weekly Liquidity is $30 \%$.

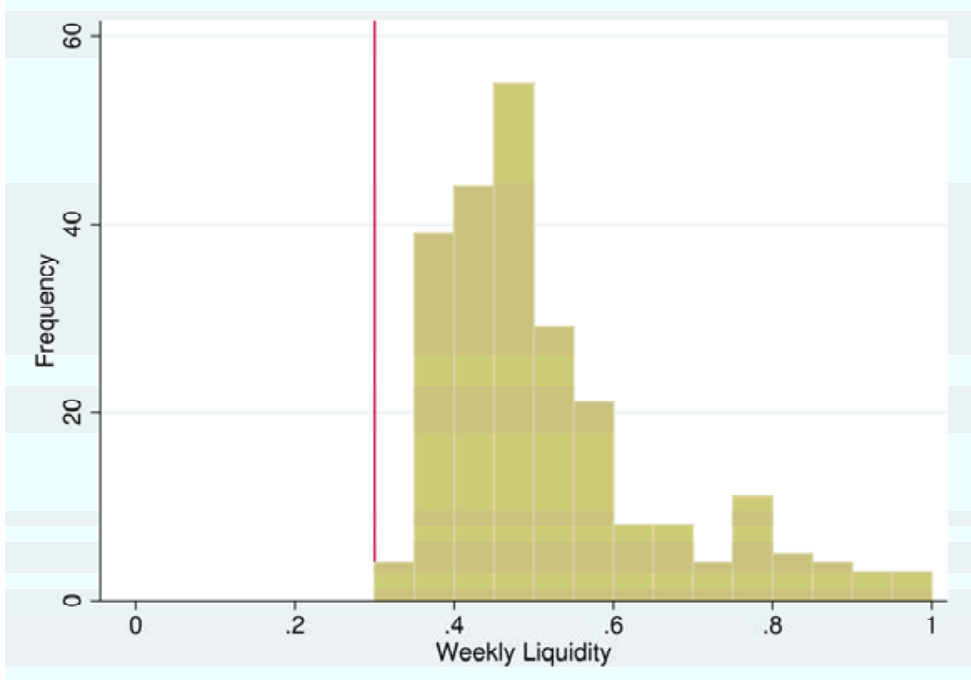




\section{Figure 4. Time series of average overnight, daily and weekly liquidity at money market mutual funds}

This figure displays the average (across all prime money market funds) Weekly Liquidity and Daily Liquidity over the sample period. Overnight Liquidity is the proportion of the fund's portfolio invested in securities maturing on the next business day. Daily Liquidity is the proportion of the fund's portfolio invested in Treasury securities as well as securities maturing on the next business day. Weekly Liquidity is the proportion of the fund's portfolio invested in Treasury securities, securities maturing within the next business day as well as certain government guaranteed securities with less than 60 days to maturity.

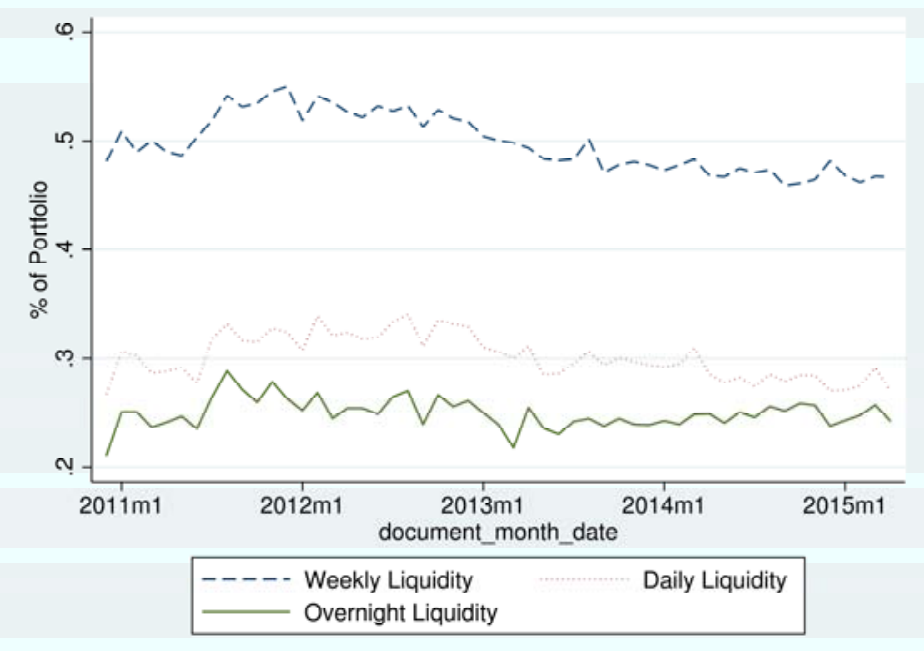

